\title{
Religion och samhällspraktik. En jämförande analys av det sekulariserade Sverige
}

\section{THORLEIF PETTERSSON}

I ett internationellt perspektiv kännetecknas den svenska kulturen av en särpräglad kombination av mycket låga nivåer för kyrkoorienterad religion och höga nivåer för en individualistisk grundhällning. Särprägeln är inte ny, och historiskt material frän ett stort antal länder ger empiriskt stöd till två motsatta modeller för kulturell förändring. Modellerna innebär att den kyrkoorienterade religionen blir starkare tack vare ökad religiös mångfald och svagare på grund av ökad välfärd. Sammantaget innebär de båda modellerna att religionen $i$ stort sett har förblivit stabil, också i Sverige, och den påverkar fortfarande hur den lokala samhällspraktiken i de svenska kommunerna är utformad.

\section{Religionen kan visa många olika ansikten}

Religion kan emellertid uppträda i de mest

Thorleif Pettersson, professor emeritus i religionssociologi vid Teologiska institutionen, Uppsala universitet. Numer är han seniorforskare på deltid vid Teologiska institutionen, Uppsala universitet, och Ersta Sköndal högskola, Stockholm. Thorleif Pettersson har under lång tid arbetat inom World Values Survey. skilda former och en undersökning av religionens plats och funktion i det svenska samhället kan knappast undvika frågan om vilka former som kommer att analyseras. Därför inleds denna artikel om religion och samhällspraktik i dagens Sverige med en kort diskussion av två olika religionsbegrepp som ger två helt olika bilder av vad religionen betyder för den svenska samhällspraktiken. De båda religionsbegreppen exemplifieras av skillnaden mellan vad 
som kan kallas "transcendensreligioner" och "immanensreligioner" (jfr. Woodhead \& Heelas 2000).

Transcendensreligioner drar isär och gör en skarp åtskillnad mellan Gud och människa och bygger på en ontologisk eller kunskapsteoretisk distinktion mellan vad som anses vara naturligt och övernaturligt. Sådana religioner wattribute authority first and foremost not to human beings nor to nature, but to the transcendent. They locate the source of all goodness and truth in the transcendent" (Woodhead \& Heelas 2000 s. 27). Immanensreligioner utgår däremot inte från någon sådan skarp åtskillnad mellan natur och övernatur. De relaterar i stället till "the intrinsic spirituality of the person or the integral spirituality of the natural order as a whole» (Woodhead \& Heelas 2000 s. 110). Exempel på immanensreligioner finns inom nyandlighet och holism. Där återfinns den yttersta auktoriteten snarare inom människan än bortom och utanför henne. Den naturliga världen är inte underordnad och radikalt avskild från en sannare och övernaturlig existens. Immanensreligioner konstitueras i stället av en sociologisk åtskillnad mellan vad som anses vara heligt och profant. Det heliga utmärks av att vara avskilt och omgärdat av tabuföreställningar som innebär att det inte får vanhelgas, ifrågasättas, bespottas.

För att undersöka vad som anses vara heligt i ett samhälle skall man fråga efter vad man under inga omständigheter får skända och smutsa ned. När man skall undersöka religion i ontologisk mening skall man i stället fråga vad människor anser står över den iakttagbara och naturliga världen. De svar man får med dessa två frågor kan ibland sammanfalla, men det som betraktas som transcendent och övernaturligt behöver inte vara heligt $i$ sociologisk mening, och det som betraktas som heligt och därmed religion i ett sociologiskt perspektiv behöver inte referera till något transcendent och övernaturligt i en ontologisk mening. Enligt 1887 års lag om religionsbrott kunde man dömas till fängelse genom att lasta eller gäcka Gud, Guds heliga ord och sakrament. Det som betraktades som transcendent och övernaturligt var med andra ord samtidigt heligt $i$ en juridisk-sociologisk mening. Från och med år 1971 finns inte längre något sådant skydd mot hädelse i svensk lagstiftning, varken i brottsbalk eller i tryckfrihetsförordning. Transcendent gudstro har i samhällets ögon blivit mindre helig, mindre tabuomgärdad och därmed mindre religion $i$ en sociologisk innebörd.

Att transcendent gudstro inte längre betraktas som helig utesluter inte att andra företeelser kan vara det. Religionssociologer framhåller allt oftare att mänskliga rättigheter, individuell autonomi och personlig integritet börjar ses som okränkbara och "heliga» värden. Dagens kompromisslösa uppslutning runt personlig integritet, självförförverkligande och individuell autonomi skulle med andra ord förläna den enskilda människan och hennes individuella rättigheter ett drag av helighet och därmed en religiös karaktär.

"The individual, the bearer of identity ens realissimum, quite logically attains a very important place in the hierarchy of values. Individual freedom, individual autonomy and individual rights come to be taken for granted as moral imperatives of fundamen- 
tal importance, and foremost of these individual rights is the right to plan and fashion one's life as freely as possible" (Berger et al. 1974 s. 73f, jfr. Luckmann 1990 s. 238).

Det skulle sannolikt inte uppröra särskilt många svenskar om man börjar häckla kyrka och prästerskap. Om man däremot på allvar började kränka någons personliga integritet och värde, särskilt det lilla oskyddade barnets, skulle sannolikt många fler bli förbittrade och upprörda. Tillspetsat kan man säga att en övernaturlig Gud har ändrat karaktär, flyttat in i de enskilda individerna och förlänat dem en religiös dimension, utan att för den skull den totala omfattningen av de religiösa uttryckssätten och föreställningarna oavsett vilken form de tar sig har blivit fler eller färre. De skulle bara ha fått ny gestalt. Religiös förändring behöver med andra ord inte enbart innebära att "det religiösa" har ökat eller minskat i omfattning. Det kan i stället räcka med att de religiösa uttryckssätten börjar visa ett nytt ansikte. En intressant problematik handlar om i vilken utsträckning detta nya ansikte uppfattas som den religion det faktiskt symboliserar.

Den senaste tidens religio-politiska spänningar runt de så kallade Muhammedkarikatyrerna kan förstås som en konflikt mellan dessa olika religionsbegrepp. Å ena sidan ses karikatyrerna i ett muslimskt perspektiv som en kränkning av ett ontologiskt motiverat religionsbegrepp som bygger på en åtskillnad mellan en överordnad gudomlighet och en underordnad människa. Karikatyrernas upphovsmän betonar däremot sin "heliga" och okränkbara individuella rätt att manifestera sin integritet och indi- viduella autonomi, det vill säga sina egna religiösa värden, också när dessa kommer i konflikt med andras religiösa symboler.

Den som vill diskutera vad religion betyder för politik och samhällsliv i dagens Sverige kan således sammanfattningsvis å ena sidan undersöka vad gudstro, kyrkor och religiösa samfund betyder i sådana hänseenden, och å andra sidan analysera vilka värden som betraktas som heliga och okränkbara och vad dessa i så fall skulle betyda. Denna artikel kommer att diskutera båda perspektiven, men framförallt det förstnämnda. Diskussionen kommer inledningsvis att föras $i$ ett jämförande perspektiv där Sverige ses i en internationell kontext. Artikeln kommer därefter att avslutas med en kortfattad diskussion av vad kyrksamheten i den svenska kontexten betyder för politik och samhälle. Avsikten med den avslutande delen är att ge en motbild till en slutsats som de internationella jämförelserna lätt kan mynna ut i, nämligen att religion skulle vara en alltigenom marginaliserad storhet i det svenska samhället.

\section{Sverige, ett land med en mycket annorlunda kultur}

Med utgångspunkt i ett antropologisktsociologiskt kulturbegrepp som inkluderar levnadsmönster, grundläggande värderingar, normer, trosföreställningar och handlingssätt som kulturella yttringar kan man konstatera att den svenska kulturen är mycket särpräglad. Detta framkommer tydligt av materialen från de mycket omfattande studierna "The European Values

Thorleif Pettersson: Religion och samhällspraktik. En jämförande analys av... 
Study" (EVS') respektive "The World Values Survey" (WVS'2). Allt som allt har ett 80-tal länder medverkat i dessa båda tvillingprojekt. Hittills har fem omgångar med personliga besöksintervjuer med stora representativa befolkningsurval om cirka 1000 - 2000 intervjupersoner i varje land genomförts åren 1981, 1990, 1995, 2000 och 2005 (se t.ex. Arts et al. 2003, Pettersson \& Esmer 2005, Pettersson 2008). Intervjuerna har handlat om svarspersonernas grundläggande värderingar, deras samhällssyn och livsåskådningar. För att ge en kort sammanfattning av dessa båda projekt när det gäller sådant som har med religion att göra kommer denna artikel att redovisa uppslutningen kring två grundläggande värdeorienteringar i ett 60-tal länder. Den första gäller kyrkoorienterad religion och den andra en individualistisk grundhållning. Resultaten kommer från den undersökning som genomfördes åren 1999-2000. De värderingsförändringar som har skett sedan dess är oftast begränsade, och skillnaderna mellan länderna har förblivit relativt oförändrade (se senare i texten om detta). Man kan därför säga att redovisningen av de förhållanden som rådde för c:a åtta år sedan också beskriver dagens situation.

\section{Att undersöka kyrkoorienterad religion och individualism}

Den kyrkoorienterade religionen är ett

1 Se http://www.europeanvaluesstudy.eu/

2 Sehttp://www.worldvaluessurvey.org/ religiöst engagemang som uttrycks inom ramen för etablerade religiösa organisationer, det vill säga i förhållande till kyrkor och samfund inom den kristna kulturen, till moskéer inom den islamiska, till tempel inom den hinduiska, etc. Begreppet »kyrkoorienterad religion" används med andra ord som en teknisk term för organiserad religion. För att studera den kyrkoorienterade religionen bygger denna artikel på fyra indikatorer. Dessa visar hur ofta man deltar i gudstjänster eller motsvarande, hur viktig man anser att religion är i ens liv, hur viktig man anser att Gud är samt i vilken utsträckning man anser att det egna samfundet förmår ge tillfredsställande svar på människors moraliska, familjemässiga och sociala problem. Detta sätt att fånga den kyrkoorienterade religionen är förhållandevis oproblematiskt och ansluter väl till en lång tradition av motsvarande studier (jfr. Glock \& Stark 1965).

När det däremot gäller den individualistiska grundhållningen kan några kortfattade teoretiska klargöranden vara på sin plats. Individualism ses ofta som motsats till kollektivism som innebär att grupper eller sociala aggregat skulle vara de grundläggande sociala enheterna eller aktörerna. Individualism skulle till skillnad häremot innebära att de enskilda individerna ses som de mest grundläggande sociala enheterna (Triandis 1994, jfr. Fiske 1991, Pettersson 2000). Det finns emellertid knappast några samhällen som skulle vara ensidigt individualistiska eller kollektivistiska i en sådan mening; de flesta utmärks i stället av olika blandningar av så kallade allocentriska (kollektivistiska) eller idiocentriska (individualistiska) föreställningar 
eller attribut. Då de allocentriska föreställningarna dominerar fokuserar den sociala perceptionen i allt väsentligt på grupper eller kollektiv som grundläggande enheter; då de idiocentriska dominerar bygger den sociala perceptionen i allt väsentligt på enskilda individer som primära aktörer. Vilka attribut som aktualiseras i en given social kontext beror på en rad faktorer. Hur individerna väljer mellan dessa två olika typer av attribut beror inte minst på vilka vanemässiga strategier de har utvecklat i dessa hänseenden. »Once a person develops a habit of using individualist elements, the switch to the use of collectivist elements requires a lot of 'cognitive work' " (Triandis 1994 s. 46). Individernas relativa antal val av allocentriska eller idiocentriska attribut kan därför användas som indikator på hur stark deras kollektivistiska eller individualistiska tendens är.

Den aktuella EVS/WVS-undersökningen ställde fyra intervjufrågor där svaren kan användas som indikatorer på idiocentriska attribut. Svaren visar i vilken utsträckning man tycker sig kunna lita på sina medmänniskor, hur viktigt man anser att det är att visa andra människor respekt och tolerans, i vilken utsträckning man accepterar invandrare och människor av annan etnisk bakgrund som grannar, samt i vilken utsträckning man omfattar en så kallad postmaterialistisk inställning som prioriterar individuell autonomi och integritet framför att bevara rådande sociala och ekonomiska strukturer. Man kan ha

\section{Tabell I.}

Resultat från en konfirmatorisk faktoranalys av 8 indikatorer på kyrkoorienterad religion och individualism. Resultat för 52940 svarspersoner frän EVS/WVS-omgängen i 57 länder år 1999/2000.

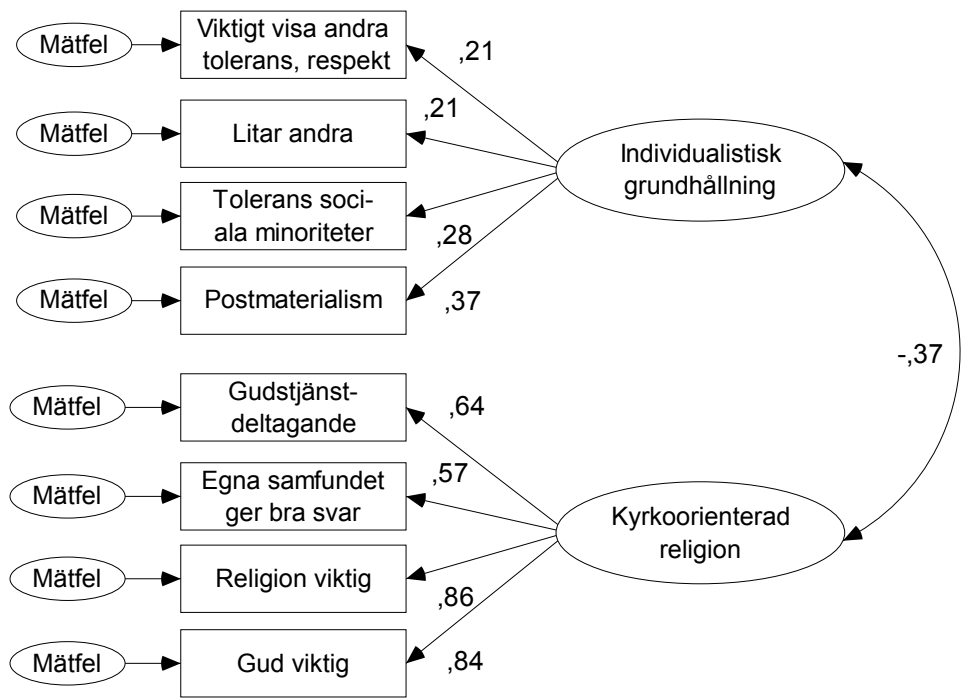

Chi-square $=377,683, \mathrm{df}=19$, Chi-square $/ \mathrm{df}=19,88, \mathrm{Agfi}=, 997, \mathrm{RMSEA}=, 019, \mathrm{p}=1,000, \mathrm{n}=52940$

Thorleif Pettersson: Religion och samhällspraktik. En jämförande analys av... 
kritiska synpunkter på om dessa intervjufrågor verkligen skulle fånga typiska idiocentriska attribut. Det är emellertid svårt att finna några bättre indikatorer $i$ det nu aktuella materialet. Med tanke på att indikatorerna enbart skall användas för en översiktlig diskussion av skillnader och likheter mellan olika länder är resultaten från den konfirmatoriska faktoranalys som redovisas i Tabell 1 tillräckliga för att visa deras användbarhet. Man bör emellertid också notera att faktorladdningarna för de fyra indikatorerna på den individualistiska grundhållningen som bäst är medelstarka. En av indikatorerna utgörs av en enkel »ja - nej«-fråga om i vilken utsträckning man tycker sig kunna lita på andra människor. Tidigare studier har visat att denna fråga är behäftad med flera problem (se t.ex. Lundåsen \& Pettersson 2009). I materialet från den senaste WVS-omgången infördes därför bättre frågor om horisontell tillit. Om man gör en motsvarande analys som i Figur 1 med ett index som bygger på dessa frågor i stället för den problematiska frågan i omgången år 2000 ökar faktorladdningarna i storlek. Problemet med materialet från den senaste WVS-omgången är emellertid att det innehåller färre länder än den föregående omgången. Av det skälet bygger artikeln på det sistnämnda materialet trots att den aktuella analysen inkluderar den problematiska tillitsfrågan.

Problemet med att utveckla tillfredsställande mått på individualism kan emellertid också ytterst ha att göra med svårigheter att studera individualism som en egenskap på individnivå. Man kan tycka att det ligger en paradox $i$ att individualism skulle visa sig genom att stora majoriteter i en befolkning skulle omfatta identiska föreställningar och värderingar! I stället kan man argumentera för att en individualistisk kultur snarare visar sig i att det finns stora variationer i de individuella föreställningarna. I denna artikel väljer jag emellertid att studera individualism som ett fenomen på individnivå.

\section{Kyrkoorienterad religion och individualism i 58 länder}

Figur 1 nedan visar hur stora andelar i de olika länderna som har uppfyllt minst två av fyra indikatorer på den kyrkoorienterade religionen respektive den individualistiska grundhållningen. Indikatorerna för den kyrkoorienterade religionen har kodats så att de visar om man deltar i gudstjänst eller motsvarande minst en gång i månaden, att man anser att religion är viktig i ens liv, att man anser att det egna samfundet ger bra svar på minst två av människors moraliska, familjemässiga och sociala problem samt att man anser att Gud är viktig i ens liv. För den individualistiska grundhållningen har indikatorerna kodats så att de visar att man tycker sig kunna lita på andra, att man tycker det är viktigt att visa andra människor tolerans och respekt, att man accepterar invandrare och människor med annan etnisk bakgrund som sina grannar samt att man har en postmaterialistisk inställning.

Resultaten ger tydligt stöd för tesen att den svenska kulturen är mycket särpräglad. Inget annat land visar så höga värden för den individualistiska grundhållningen, samtidigt som Sverige ligger mycket lågt i den kyrkoorienterade religionen. För att 
knyta an till de båda religionsbegrepp som beskrevs i artikelns inledning kan man konstatera att den kyrkoorienterade religionen i jämförelse med andra länder är mycket marginaliserad i Sverige samtidigt som uppslutningen kring en individualistisk grundhållning är betydligt starkare. I vilken utsträckning den senare inställningen kan karaktäriseras som en uppslutning runt ett "heligt" värde kan naturligtvis problematiseras. Tyvärr finns inga uppgifter i det aktuella materialet som kan belysa denna fråga på ett helt tillfredsställande sätt. Hur som helst kan man notera att de indikatorer som har använts för att fånga den individualistiska grundhållningen ligger nära de indikatorer som brukar användas för att undersöka Ronald Ingleharts välkända »self- expression values». Dessa har i varje fall drag av sådan uppslutning kring en individualistisk tendens som en hög värdering av "individuell helighet« antyder.

När man analyserar var länderna placerar sig i den kyrkoorienterade religionen och den individualistiska grundhållningen finner man inte oväntat några tydliga mönster. Om man först ser till den kyrkoorienterade religionen visar sig denna vara svagast $\mathrm{i}$ de länder som har hunnit längst $\mathrm{i}$ ekonomisk och social utveckling. En sådan relation ligger i linje med vad klassisk sekulariseringsteori brukar anta (se senare i artikeln om detta). Som mått på sådan utveckling kan man använda $\mathrm{FN}$ :s så kallade Human Development Index (HDI) som kombinerar tre aspekter: ekonomisk

\section{Figur I.}

Kyrkoorienterad religion och individualism i 57 länder. Resultat frän EVS/WVS-omgången år 2000. Länderförkortningar enligt ISO-3166-1 alpha3

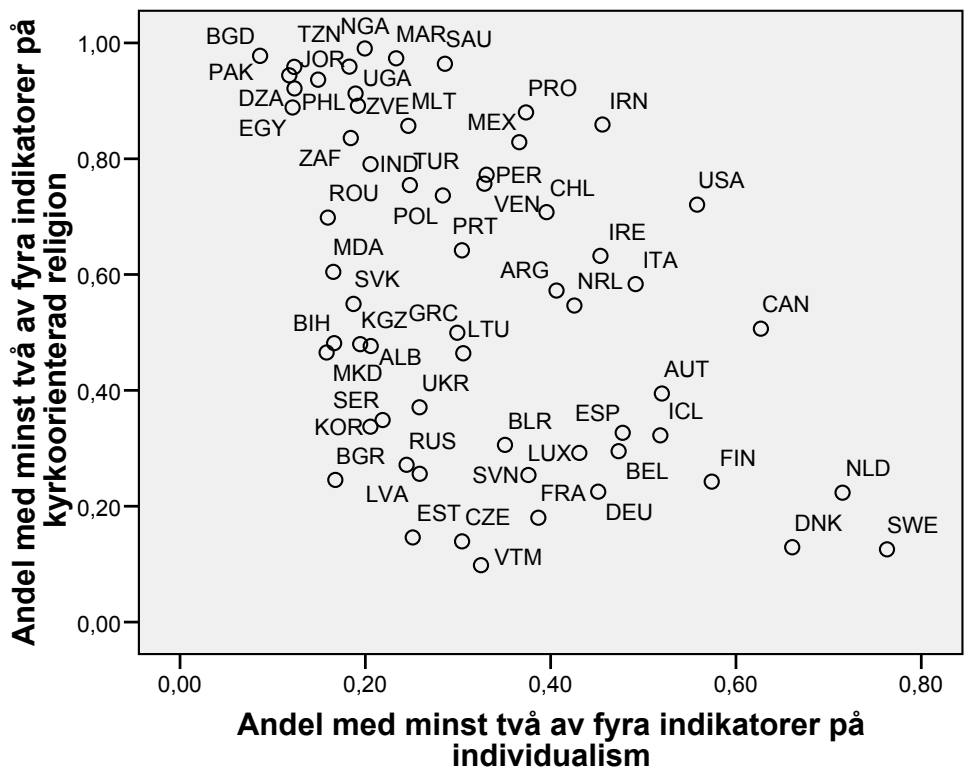

Thorleif Pettersson: Religion och samhällspraktik. En jämförande analys av... 
utveckling (BNP per capita), utbildning (andel läskunniga i befolkningen över 15 år) samt hälsa (förväntad livslängd vid födelsen). Vid sidan av denna faktor visar det sig dessutom att länder med en islamisk och katolsk religiös tradition har högre värden för den kyrkoorienterade religionen än länder med protestantisk och blandad religiös tradition. ${ }^{3}$ De aktuella faktorerna förklarar inte mindre än c:a två tredjedelar av skillnaderna mellan länderna i den kyrkoorienterade religionen. När det gäller den individualistiska grundhållningen visar sig denna vara starkast i länder som har hunnit längst i ekonomisk och social utveckling (HDI-indexet). Samma sak gäller för de länder som har högst värden i Världsbankens så kallade "Rule of law-index» (Kaufmann et al. 2006). Detta index anger i vilken utsträckning ländernas juridiska system är rättvisa och transparenta och utgör ett effektivt skydd mot övergrepp mot de enskilda medborgarnas integritet. ${ }^{4}$ Indexet har också en tydlig koppling till hur demokratiserade länderna är. ${ }^{5}$ De aktuella

3 Den ostandardiserade regressionsekvationen är: Kyrkorienterad religion $=1,37-\left(1,29^{*} \mathrm{HDI}\right)$ $+\left(0,04{ }^{*}\right.$ muslimsk tradition $)+\left(0,04{ }^{*}\right.$ katolsk tradition $)+\left(0,01{ }^{*}\right.$ protestantisk tradition $)$. De tre förstnämnda oberoende variablerna är signifikanta: $\mathrm{p}<, 02$. Länder med blandad religiös tradition referenskategori. $\mathrm{R} 2=, 66$.

4 Den ostandardiserade är: Individualism $=-0,25$ $+\left(0,41^{*} \mathrm{HDI}\right)+\left(0,07^{*}\right.$ rule of law $)$. Bägge oberoende variablerna är signifikanta; $\mathrm{p}<, 0,01$. R2 $=, 76$.

5 Korrelationen mellan rule of law-indexet och Freedom House's så kallade Polity4 index för graden av demokrati är .59 för de 188 länder där det finns uppgifter om båda indexen. faktorerna förklarar inte mindre än c:a tre fjärdedelar av skillnaderna mellan länderna i den individualistiska grundhållningen. De aktuella sambanden mellan de båda värdeorienteringarna och de aktuella strukturvariablerna visar sig för övrigt också vid mer detaljerade flernivåanalyser där man också tar hänsyn till betydelsen av individuella faktorer som kön, ålder och utbildning. De aktuella resultaten kan för övrigt också sägas visa att måtten på de båda värdeorienteringarna har acceptabel validitet.

Materialet visar således att uppslutningen runt den kyrkoorienterade religionen och den individualistiska grundhållningen samvarierar med ländernas varierande ekonomiska och sociala utveckling, rättssäkerhet, demokratisering och religiösa tradition. Man bör dock vara försiktig med att tolka dessa mönster i termer av ensidiga orsakssamband så att styrkan hos de strukturella faktorerna skulle förklara styrkan hos de individuella värdeorienteringarna. De statistiska sambanden bör snarare tolkas så att de strukturella faktorerna påverkar de individuella värdeorienteringarna som i sin tur påverkar de strukturella faktorerna i en fortgående växelverkan.

\section{Sverige har en mycket särpräglad kultur}

Sverige placerar sig således längst ned till höger i Figur 1. Om man för vart och ett av länderna beräknar avståndet till figurens mittpunkt finner man att Sverige visar det största avståndet av alla. Därefter kommer Danmark, Holland, Vietnam, Bangladesh 
och Nigeria. Det land som ligger närmast figurens mittpunkt är Grekland följt av Portugal, Argentina, Litauen och Slovakien. Svenskarna kännetecknas med andra ord av den mest atypiska och avvikande profilen av alla när det gäller den kyrkoorienterade religionen och den individualistiska grundhållningen! Inget annat folk visar så långt avstånd till medelvärdet för det totala antalet länder. Denna särpräglade svenska kultur visar sig för övrigt också när man analyserar mer teoretiskt definierade och »heltäckande» värdeorienteringar, till exempel de som bygger på Ronald Ingleharts och Shalom Schwartz teoretiska modeller (se t.ex. Pettersson 2008, Pettersson \& Esmer 2005, Pettersson \& Nurmela 2007). Oavsett om man ser till religion och individualism eller till teoretiskt definierade och mer grundläggande värderingsdimensioner kan man således konstatera att Sverige är ett kulturellt mycket annorlunda land. Denna kulturella särprägel kan åtminstone delvis ses som uttryck för en lång historisk tradition som bland annat inkluderar speciella maktrelationer mellan en stark stat och en fri självägande bondeklass tillsammans med frånvaro av ett feodalt samhällsskick (se t.ex. Österberg 1993, Blanck \& Pettersson 2006). Traditionen innebar att lagens och statens legitimitet inte blev pådyvlad uppifrån utan att den istället utvecklades som en konsekvens av sekellånga förhandlingar i ett samhälle där den sociala och politiska friheten var stor (Trägårdh 2009 s. 219). Man har också pekat på betydelsen av ett långvarigt svensk-nordiskt äktenskapsmönster. Mönstret innebar bland annat att kvinnor gifte sig jämförelsevis sent, att hushållsbildningen var oberoende av för- äldrahemmet samt att barnen ofta arbetade i utomstående hushåll som hade behov av arbetskraft. Också dessa förhållanden har sagts underlätta framväxten av frihet och social tillit (Trägårdh 2009 s. 215f).

För att ge en mer detaljerad bild av skillnaderna mellan länderna visar Tabell 2 nedan resultat för nio av dem. Dessa nio länder har valts så att de ligger på ungefär lika långt avstånd från varandra längs en tänkt diagonal i Figur 1 från det övre vänstra hörnet (stark kyrkoorienterad religion, svag individualism) till det nedre högra (svag kyrkoorienterad religion, stark individualism). Tabellen visar ungefärligen samma spännvidd mellan de lägsta och högsta värdena i både den kyrkoorienterade religionen och den individualistiska grundhållningen (medelvärdet för de fyra indikatorerna är ungefär tre gånger så stort vid det högsta värdet som vid det lägsta). Sverige visar således de lägsta procenttalen för var och en av de fyra indikatorerna på den kyrkoorienterade religionen. Om dessa procenttal också kan sägas vara låga i en absolut mening är emellertid en helt annan fråga. Att cirka en tredjedel av svenskarna $(35,7$ procent $)$ anser att religion är viktig i det egna livet, att knappt var femte (17 procent) anser att gud är viktig, att knappt var tionde $(9,7$ procent) deltar regelbundet i gudstjänst minst en gång i månaden samt att en ungefärlig sjundedel (13,9 procent) anser att det egna samfundet ger bra svar inom minst två av tre moraliska problemområden (moraliska, familjemässiga och sociala) kan knappast sägas innebära att den kyrkoorienterade religionen skulle vara mer eller mindre försvunnen från det svenska religiösa landskapet. Även om Sve-

Thorleif Pettersson: Religion och samhällspraktik. En jämförande analys av... 


\begin{tabular}{|c|c|c|c|c|c|c|c|c|c|c|c|c|c|c|c|}
\hline$\sum_{i=1}^{\infty}$ & 彥 & & 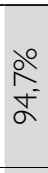 & $\begin{array}{l}\text { ठ̊ } \\
\text { बे }\end{array}$ & $\frac{\partial}{\stackrel{\circ}{\alpha}}$ & 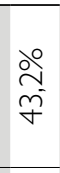 & $\begin{array}{l}\stackrel{0}{1} \\
\infty\end{array}$ & & $\begin{array}{l}\text { よे } \\
\text { बे }\end{array}$ & $\begin{array}{l}\text { o̊ } \\
\infty \\
\text { గ̂ } \\
\text { గn }\end{array}$ & $\frac{\stackrel{\circ}{\circ}}{\text { जூ }^{-}}$ & $\stackrel{\circ}{\stackrel{\circ}{\sim}} \underset{+}{+}$ & $\begin{array}{l}\text { ळे } \\
\text { bे }\end{array}$ & 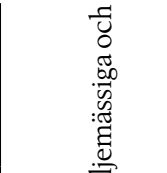 & 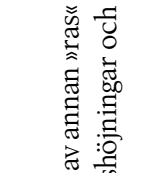 \\
\hline$\frac{\frac{a}{3}}{\frac{\pi}{5}}$ & త্ర & & 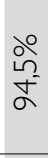 & 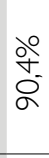 & $\begin{array}{l}\text { ठ̊ } \\
\text { ō } \\
\infty\end{array}$ & $\begin{array}{l}\text { ○̊ } \\
\infty \\
\text { ஸ́ } \\
\end{array}$ & 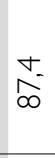 & & $\begin{array}{l}\stackrel{0}{0} \\
\AA^{-1}\end{array}$ & $\frac{\alpha^{\circ}}{\omega^{-}}$ & $\frac{\stackrel{\circ}{\stackrel{0}{0}}}{\frac{1}{1}}$ & $\stackrel{\stackrel{\circ}{m}}{\tilde{N}}$ & $\begin{array}{l}\stackrel{\circ}{0} \\
\text { రे } \\
m\end{array}$ & 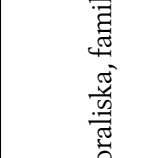 & 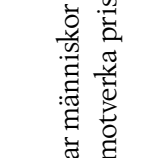 \\
\hline 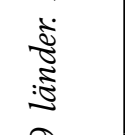 & $\underline{\underline{\mathbf{z}}}$ & & 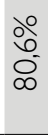 & $\begin{array}{l}\stackrel{\circ}{\alpha} \\
\text { à }\end{array}$ & 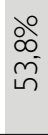 & $\begin{array}{l}\text { ఏొ } \\
\text { å }\end{array}$ & $\frac{N}{6}$ & & $\frac{\grave{d o}}{\sigma}$ & $\begin{array}{l}\stackrel{d}{\leftarrow} \\
\text { ஸे }\end{array}$ & $\begin{array}{l}\stackrel{\circ}{\mathrm{m}} \\
\text { ஸे }\end{array}$ & $\begin{array}{l}\text { ○’ } \\
\infty \\
\infty \\
\infty\end{array}$ & $\begin{array}{l}\stackrel{0}{0} \\
\infty \\
\stackrel{y}{+}\end{array}$ & 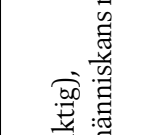 & 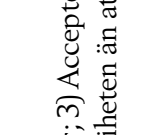 \\
\hline$\frac{\sqrt{2}}{3}$ & $\stackrel{\Upsilon}{\mathfrak{r}}$ & & $\begin{array}{l}\stackrel{\partial}{+} \\
\text { à }\end{array}$ & $\frac{\partial^{\circ}}{\sigma^{-}}$ & $\begin{array}{l}\text { do } \\
\text { à } \\
\text { ma }\end{array}$ & $\frac{\partial 0}{\text { जु }}$ & $\frac{\llcorner 2}{\Lambda}$ & & $\frac{x^{\circ}}{\underline{6}^{-}}$ & 犬े & $\begin{array}{l}\text { ๙ે } \\
\text { స్- } \\
\text { ผn }\end{array}$ & 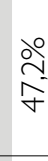 & $\begin{array}{l}\stackrel{\partial}{+} \\
\stackrel{5}{\sigma}\end{array}$ & 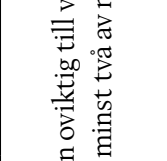 & 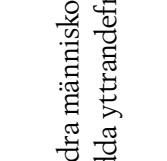 \\
\hline 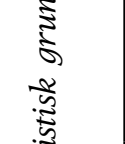 & $\stackrel{\frac{5}{a}}{a}$ & & 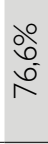 & $\frac{\partial^{\circ}}{\text { mु }^{-}}$ & 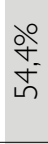 & $\frac{\partial 0}{a^{-}}$ & $\begin{array}{l}m \\
\infty^{\infty} \\
\mathfrak{n}^{\prime}\end{array}$ & & $\begin{array}{l}\stackrel{\circ}{\text { m }} \\
\text { N }\end{array}$ & $\begin{array}{l}\text { बे } \\
\text { бे } \\
\sigma\end{array}$ & $\begin{array}{l}\text { do } \\
\text { నू } \\
\text { on }\end{array}$ & $\frac{\text { ㅇำ }}{\mathrm{m}}$ & $\begin{array}{l}\text { 을 } \\
\text { స̃ }\end{array}$ & 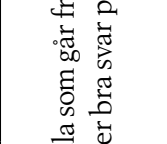 & 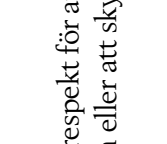 \\
\hline 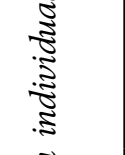 & $\begin{array}{l}0 \\
\frac{\alpha}{\alpha}\end{array}$ & & $\begin{array}{l}\text { ठ̊ } \\
\text { ભ̀ } \\
\text { N }\end{array}$ & 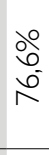 & $\stackrel{\text { ํ}}{\stackrel{\text { m}}{+}}$ & $\begin{array}{l}\text { do } \\
\text { } \\
\text { o } \\
\text { o }\end{array}$ & $\begin{array}{l}t \\
0 \\
0\end{array}$ & & $\begin{array}{l}\text { do } \\
\infty \\
\text { जీ } \\
\underline{-1}\end{array}$ & $\begin{array}{l}\stackrel{\circ}{m} \\
\stackrel{2}{0}\end{array}$ & $\frac{\text { ळे }}{\sigma}$ & 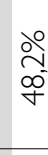 & 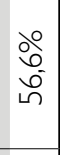 & 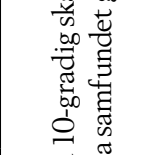 & 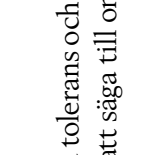 \\
\hline 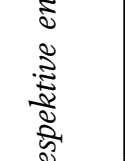 & $\frac{5}{4}$ & & 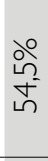 & $\begin{array}{l}\text { ㅇํำ } \\
\text { fo }\end{array}$ & 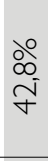 & $\frac{\partial 0}{\sqrt{~}}$ & $\widehat{\mathcal{F}}$ & & $\begin{array}{l}\stackrel{\circ}{\mathrm{m}} \\
\stackrel{5}{m}\end{array}$ & $\stackrel{\circ}{\stackrel{ }{N}}$ & $\begin{array}{l}\text { よ̊ } \\
\text { ஸे } \\
\infty\end{array}$ & $\begin{array}{l}\text { مे } \\
\text { ผn }\end{array}$ & $\begin{array}{l}\text { ठ̊ } \\
\text { ๙ิ }\end{array}$ & 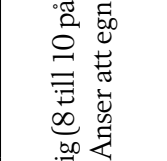 & 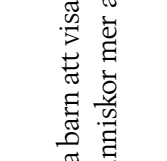 \\
\hline 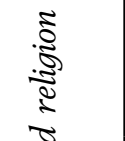 & $\frac{\mathbf{Z}}{\mathbf{u}}$ & & $\begin{array}{l}\text { ठ̊ } \\
\text { mे } \\
\text { †े }\end{array}$ & $\frac{\partial 0}{\frac{N}{m}}$ & $\begin{array}{l}\stackrel{\circ}{\stackrel{0}{+}} \\
\text { m- }\end{array}$ & $\begin{array}{l}\text { ○’ } \\
\infty \\
\text { बे }\end{array}$ & ڤ̄ & & 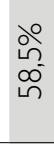 & $\begin{array}{l}\text { ○े } \\
\text { mं } \\
\infty\end{array}$ & $\begin{array}{l}\text { 우 } \\
\text { ஸे } \\
\infty\end{array}$ & $\frac{\stackrel{\circ}{+}}{\mathrm{m}}$ & 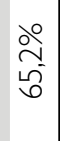 & 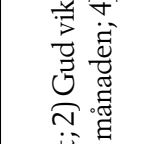 & 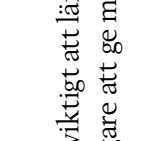 \\
\hline 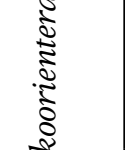 & $\frac{\omega}{3}$ & & $\frac{d 0}{\hat{N}^{n}}$ & $\frac{\text { ᄋ̊ }}{\stackrel{0}{-}}$ & $\begin{array}{l}\stackrel{\circ}{+} \\
\text { ă }\end{array}$ & $\begin{array}{l}\text { 으 } \\
\text { m- }\end{array}$ & 으 & & $\stackrel{\circ}{\stackrel{\jmath}{\sigma}}$ & ঐे & $\begin{array}{l}\text { do } \\
\text { } \\
\text { ă }\end{array}$ & $\frac{\partial}{\sigma}$ & $\begin{array}{l}\text { ठ̊ } \\
\text { N- }\end{array}$ & 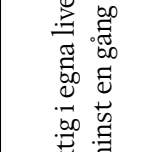 & 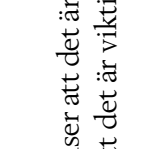 \\
\hline 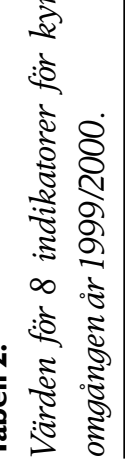 & & 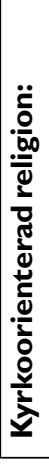 & 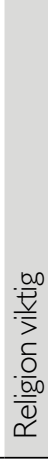 & $\frac{.00}{\frac{00}{2}}$ & 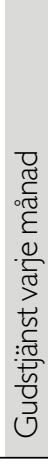 & 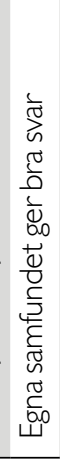 & 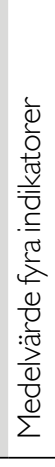 & 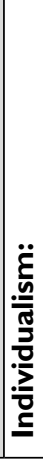 & 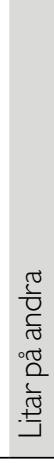 & 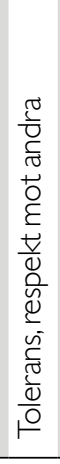 & 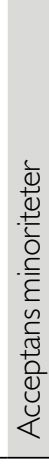 & 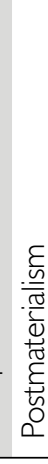 & 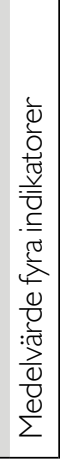 & 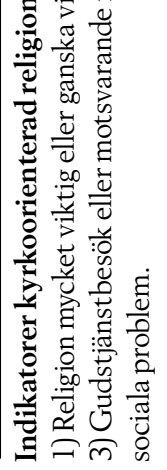 & 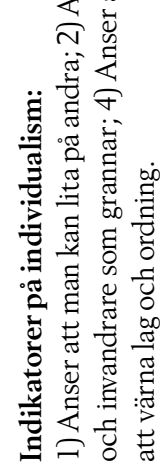 \\
\hline
\end{tabular}

Socialvetenskaplig tidskrift nr 3-4 • 2009 
rige är ett av världens mest sekulariserade länder och den kyrkoorienterade religionen förvisso har minskat kraftigt under det senaste seklet visar dessa nivåer snarare att man inte behöver leta särskilt länge för att hitta svenskar som ger uttryck för en omisskännlig kyrkoorienterad religion.

I samma riktning pekar resultaten från den så kallade "Millennieräkning" som genomfördes år 1999. Då kartlades en rad aspekter av det religiösa livet i Sverige. Resultaten visade att cirka 487000 gudstjänstbesök eller motsvarande ägde rum under ett typiskt veckoslut (fredag - söndag). Det var enbart besök vid något idrottsevenemang som visade klart högre värden (1 026000 besök). De sammanlagda besöken vid nöjesevenemang som exempelvis diskotek, nattklubbar eller danstillställningar var enbart marginellt fler än gudstjänstbesöken (547 000), medan biobesöken, besöken vid marknads- och hembygdsdagar, teater, konsert- eller musikföreställningar, utställningar, föreningsmöten, bingo, etc., var betydligt färre (Pettersson 2001 s. 261). Att Sverige i jämförelse med andra länder visar mycket låga nivåer för den kyrkoorienterade religionen utesluter med andra ord inte att denna fortfarande har en inte obetydlig omfattning och att det finns fog för talet om dess »envetna vägran att försvinna».

När det gäller den individualistiska grundhållningen visar Sverige med ett smärre undantag de högsta värdena vid var och en av de fyra indikatorerna. Man bör särskilt uppmärksamma de höga värdena för horisontell social tillit och vikten av att visa sina medmänniskor respekt och tolerans. Sverige har i en rad olika undersökningar legat i topp när det gäller sådana aspekter som ofta ses som uttryck för så kallat socialt kapital, det vill säga ett fenomen som allt oftare anses vara en grundläggande kulturell resurs för social, ekonomisk och politisk utveckling (se t.ex. Putnam 2001, Pettersson \& Esmer 2005, Rothstein 2001, Pettersson \& Lundåsen 2009). Man bör därför vara försiktig med att sätta likhetstecken mellan individualism och "individuell egoism». En jämförelse mellan den individualistiska grundhållningen och Shalom Schwartz så kallade självöverskridande värderingar (se senare i artikeln om dessa) visar exempelvis att de mest individualistiska inte är mindre intresserade av det gemensamma bästa än de som är mindre individualistiska. En mer detaljerad jämförande analys av samma problematik visar för övrigt en liknande bild (Welzel 2009).

\section{Ökad individualism, oförändrad kyrkoorienterad religion?}

I diskussioner om kulturell förändring sägs ofta att dagens medborgare skulle bli alltmer individualistiska. När det däremot gäller religion brukar två motsatta bilder stå emot varandra. Ibland sägs att de senaste seklens religiösa tillbakagång fortsätter oförminskad; ibland hävdas i stället att samtiden skulle utmärkas av "religionens återkomst». Tabell 3 nedan visar några resultat från den senaste 15 -årsperioden i dessa båda hänseenden. Resultaten för de 13 länder som redovisas kommer från EVS/ WVS-undersökningarna år 1990 och 2006. Länderna har valts för att representera olika kulturella traditioner där Sverige och 
Norge representerar den nordeuropeiska protestantiska kulturen, Frankrike och Spanien den europeiska katolska, Polen och Slovenien en katolsk och postsovjetisk, USA och Kanada det religiösa blandade Nordamerika, Brasilien och Chile det katolska Latinamerika, Turkiet islam samt slutligen Indien och Kina, två asiatiska länder, det ena hinduiskt och det andra ett officiellt ateistiskt land med fem accepterade religiösa traditioner under statlig kontroll (katolicism, protestantism, buddhism, islam och taoism).

Resultaten visar att de kulturella förändringarna var mycket begränsade i dessa 13 länder under den senaste 15-årsperioden, det vill säga en period som ofta sägs vara starkt påverkad av det forna Sovjetväldets fall och en ständigt växande globalisering. Den kyrkoorienterade religionen förblev oförändrad samtidigt som den individualistiska grundhållningen ökade marginellt. Eftersom de sammanlagda resultaten för samtliga länder bygger på ett stort antal svarspersoner är dock ökningen statistiskt säkerställd. Om man emellertid ser till de enskilda länderna blir bilden betydligt mer sammansatt: Den kyrkoorienterade religionen ökade något $\mathrm{i}$ sju länder (Norge, Polen, Slovenien, USA, Kanada, Chile, Turkiet), minskade något i tre (Frankrike, Indien, Kina) och förblev stabil i tre (Sverige, Spanien, Brasilien). Den individualistiska grundhållningen växte sig något starkare i fem länder (Sverige, Norge, Polen, Slovenien, Brasilien), minskade något i sju (Frankrike, Spanien, USA, Chile, Indien, Kina, Turkiet) samt förblev stabil i ett (Kanada). Det är svårt att finna några gemensamma nämnare bakom dessa skilda utvecklingstendenser och den övergripande slutsatsen blir att förändringarna var marginella samt att de hade olika riktning i olika länder. Det ligger därför nära till hands att anta att specifika inhemska faktorer spelade en inte obetydlig roll för vad som skedde i respektive land. Åtminstone några av tendenserna kan dessutom vara resultat av olika felkällor, till exempel inte helt jämförbara urval och/eller undersökningsinstrument vid de båda undersökningstillfällena. Det är med andra ord svårt att finna tecken på tydliga och likartade kulturella förändringar i det aktuella materialet, och man bör hellre tala om "tidsandans krumbukter" än om odiskutabla tecken på en gemensam global kulturell förändring som skulle ha påverkat alla länder på ett likartat sätt under den senaste 15-årsperioden. Resultaten ger kort och gott knappast stöd för det myckna talet om en »kulturell McDonaldisering» som skulle ha gjort världen mer homogen i kulturella hänseenden under de senaste decennierna.

\section{Två konkurrerande uppfattningar om sekularisering}

En central religionssociologisk problematik handlar om varför styrkan hos den kyrkoorienterade religionen varierar så tydligt över tid och rum. Frågan diskuteras ofta $i$ termer av sekularisering. Eftersom det inte finns en enda allmänt accepterad sekulariseringsteori har frågan också fått många olika svar. Man bör i stället tala om ett sekulariseringsparadigm, det vill säga ett helt knippe med olika teorier eller teoretiska modeller 
för vad som skulle vara sekularisering och vilka faktorer som driver den (Gorski 2000). Att dessa olika modeller dessutom ofta har släktskap med olika moderniseringsteorier gör inte saken lättare.

\section{Sekularisering på tre nivåer}

Sekularisering studeras ofta på tre olika nivåer, nämligen på makro- eller samhällsnivå, på meso- eller organisationsnivå och slutli- gen på mikro- eller individnivå (Dobbelaere 2002). En viktig problematik gäller hur sekulariseringsprocesser på dessa olika nivåer hänger samman och påverkar varandra.

På samhällsnivå innebär sekularisering att de religiösa institutionerna som en konsekvens av samhällets differentiering har förlorat något till förmån för de sekulära. Förlusterna kan exempelvis gälla egendom, makt, inflytande, legitimitet och folklig förankring. Förlusterna kan också innebära att de religiösa institutionerna förlorar

\section{Tabell 3.}

Medelvärden för två index för kyrkoorienterad religion och individualism år 1990 och 2006 $i 13$ länder. Vardera av indexen bygger på fyra dichotomiserade indikatorer och kan variera mellan värdena 0 och 4. Antal svarspersoner per land och år cirka 1000. Ovägda medelvärden.

\begin{tabular}{|c|c|c|c|c|c|c|}
\hline & \multicolumn{3}{|c|}{ Kyrkoorienterad religion } & \multicolumn{3}{|c|}{ Individualism } \\
\hline Land: & 1990 & 2006 & Förändring? & 1990 & 2006 & Förändring? \\
\hline Sverige & 1,62 & 1,60 & Stabilitet & 2,90 & 3,07 & Ökning; $p<, 00$ I \\
\hline Norge & ।,55 & 1,78 & Ökning; $\mathrm{p}<, 00$ I & 2,33 & 2,99 & Ökning; $p<, 00$ I \\
\hline Frankrike & 1,56 & 0,94 & Minskning & 2,32 & 2,07 & Minskning; $p<, 001$ \\
\hline Spanien & 1,71 & 1,74 & Stabilitet & 2,26 & 2,12 & Minskning; $\mathrm{p}<, 00$ I \\
\hline Polen & 1,39 & 2,02 & Ökning $p<, 001$ & 1,90 & 2,20 & Ökning; $p<, 00$ I \\
\hline Slovenien & ।,37 & 1,64 & Ökning; $\mathrm{p}<, 00$ I & ।,73 & 2,13 & Ökning; $p<, 00$ I \\
\hline USA & 1,78 & 1,89 & Ökning; <,00। & 2,58 & 2,50 & Minskning; $\mathrm{p}<, \mathrm{O}$ I \\
\hline Kanada & 1,69 & 1,82 & Ökning; <,00। & 2,81 & 2,77 & Stabilitet \\
\hline Brasilien & 2,07 & 2,05 & Stabilitet & 1,92 & 1,99 & Ökning; $p<, 05$ \\
\hline Chile & 1,64 & 1,95 & Ökning; $\mathrm{p}<, 00$ I & 2,25 & 2,18 & Minskning; $p<, 05$ \\
\hline Indien & 2,14 & ।,79 & Minskning; $p<, 00$ I & 1,69 & ।,37 & Minskning; $p<, 001$ \\
\hline Kina & 0,97 & 0,76 & Minskning; $\mathrm{p}<, 001$ & 2,19 & 1,99 & Minskning; $\mathrm{p}<, 00$ I \\
\hline Turkiet & 1,35 & 1,70 & Ökning; $p<, 001$ & ।,78 & 1,67 & Minskning; $p<, 0$ I \\
\hline Samtliga & 1,69 & 1,69 & Stabilitet & 2,17 & 2,20 & Ökning; $p<, 02$ \\
\hline
\end{tabular}

Thorleif Pettersson: Religion och samhällspraktik. En jämförande analys av... 
funktioner som de tidigare har haft ansvar för, till exempel att svara för social omsorg, vård och utbildning. På samhällsnivå innebär således sekularisering att de religiösa institutionerna på grund av en ökad differentiering mellan de sekulära och religiösa institutionerna får minskad betydelse för hur samhällslivet utformas. Funktionsförlusterna innebär samtidigt att de religiösa institutionerna blir alltmer inriktade på religion i snäv mening. Det kan tyckas paradoxalt att sekularisering skulle innebära att de religiösa institutionerna blir alltmer koncentrerade på rent religiösa aspekter.

På mesonivå innebär sekularisering att de religiösa organisationerna anpassar sig till de sekulära institutionerna och de rådande samhälleliga normerna. De blir alltmer byråkratiserade och får ett alltmer professionellt ledarskap. Beslutsprocesserna inom de religiösa institutionerna börjar också likna motsvarande processer inom det sekulära samhället. Medlemskapet i de religiösa organisationerna blir samtidigt mer likformigt med medlemskap i sekulära organisationer.

På individnivå handlar sekularisering enligt Dobbelaeres modell om "compartmentalization" eller "secularization-inmind«. På svenska kan man säga »kompartmentalisering" eller "mental sekularisering". Denna form av sekularisering gäller i vilken utsträckning den faktiska åtskillnaden eller differentieringen mellan de sekulära och religiösa institutionerna på samhällsnivå motsvaras av en parallell mental åtskillnad på individnivån, det vill säga i vilken utsträckning människors religiösa föreställningar och engagemang har någon faktisk betydelse för vad de anser i sociala, politiska och ekonomiska frågor och hur önskvärd de anser att en sådan betydelse skulle vara.

\section{Vad orsakar sekularisering?}

Under de senaste decennierna har frågan om religionens samhälleliga ställning fått förnyad aktualitet och många har börjat kritisera de tidigare sekulariserings- och moderniseringsteorierna för att de alltför ensidigt förutspådde en obeveklig religiös tillbakagång. Det finns flera anledningar till att frågan om religionens ställning möts av ökat intresse. För det första har de ensidiga teorierna om mer eller mindre enhetliga moderniseringsprocesser med en ständig fortgående religiös tillbakagång som följd börjat ge vika för mer nyanserade uppfattningar om "multipla moderniteter" som kan ha helt olika konsekvenser för religionens del (se t.ex. Sachsenmaier \& Riedel 2002). Man behöver med andra ord inte automatiskt utgå från att de länder som idag genomgår en snabb moderniseringsprocess skulle komma till samma slutresultat för religionens del som de länder som moderniserades för ett sekel sedan. På motsvarande sätt har den kyrkoorienterade religionens envetna vägran att "dö ut" tillsammans med den snabba globaliseringen och en ökad religiös pluralism bidragit till mer nyanserade synsätt på religiös förändring (Bäckström 2008). När det gäller hypotesen om kyrkornas förlorade inflytande har man pekat på hur religiösa talesmän i ökad utsträckning söker motverka religionens minskade betydelse samt att de inte så sällan också lyckas i sina försök. Här kan man nämna befrielseteologernas 
ökade betydelse i Latinamerika, utvecklingen i Iran efter shahens fall, den katolskt influerade Solidaritetsrörelsen i Polen och det ökade politiska inflytandet från "the moral majority" i USA. En utveckling mot en alltmer försvagad kyrkoorienterad religion utan inflytande ses med andra ord inte längre som någon naturnödvändighet, och hypoteser om återkommande resakraliseringsprocesser börjar bli vanligare (se t.ex. Casanova 1994, jfr. Berger 1999). Man har också framhållit att den faktiska differentieringen mellan de religiösa och samhälleliga institutionerna inte nödvändigtvis står i samklang med vad människor anser om religionens samhälleliga betydelse (Dobbelaere 2002). Även om de religiösa institutionerna har förlorat i samhällelig betydelse kan medborgarna anse att religionen borde ha större betydelse; om de religiösa institutionerna fortfarande har sådan betydelse kan de önska att situationen vore den omvända (jfr. ovan om "mental sekulariseringu). Och människors subjektiva uppfattningar i dessa frågor kan sedan i sin tur påverka den faktiska samhällsutvecklingen.

\section{Två teoretiska perspektiv på sekularisering}

En stor del av dagens sekulariseringsteoretiska diskussioner förs mellan två konkurrerande teoribildningar, en äldre och en nyare. Övergången till den nyare ses ofta som tecken på ett paradigmskifte inom religionssociologin (Repstad 1996). Den äldre teoribildningen fokuserade på vad ekonomisk utveckling och samhällelig differentiering betyder för religionens del, medan den nyare pekar på betydelsen av hur de religiösa organisationerna är organiserade. Medan den äldre teoribildningen betonade vikten av religiösa monopol lägger den nya stor vikt vid ett mer mångsidigt religiöst utbud.

"The traditional paradigm in the sociology of religion sees strength in the religious monopolies, attributing to them the ability to sustain an unchallenged, taken for granted scared canopy. The newer paradigm regards religious monopolies as weak, locating religious vitality in pluralism and competition" (Stark \& McCann 1993 s. 111).

De båda perspektiven utgår med andra ord från att olika sidor av samhällsutvecklingen får olika konsekvenser för religionens del, och de kan kortfattat beskrivas som följer:

Tes 1: Modernisering och ekonomisk utveckling försvagar kyrkoorienterad religion: Som företrädare för detta synsätt kan man peka på de amerikanska statsvetarna Pippa Norris och Ronald Inglehart. De har med kraft drivit tesen att ekonomisk och social utveckling och framförallt den därmed sammanhängande ökade existentiella säkerheten och tryggheten underminerar kyrkoorienterad religion: "the experiences of growing up in less secure societies will heighten the importance of religious values, while conversely experience from more secure conditions will lessen it" (Norris \& Inglehart 2004 s. 18, kursiv i originalet). Deras grundläggande utgångspunkt är att religionen bidrar till att motverka existentiell osäkerhet och att behovet av denna funktion är störst i kontexter som har de sämsta

Thorleif Pettersson: Religion och samhällspraktik. En jämförande analys av... 
ekonomiska förutsättningarna och som är mest präglade av faktisk otrygghet. Behovet visar sig enligt dem både på individ- och samhällsnivå, även om det skulle vara mest märkbart på den senare.

Med hjälp av material från ett 80-tal länder visade Norris och Inglehart att omfattningen av ett religiöst engagemang i olika länder "could, indeed, be predicted with considerable accuracy from a society's level of economic development and other indicators of human development" (Norris \& Inglehart 2004 s. 220). Samtidigt framhöll de att ekonomisk och social utveckling inte nödvändigtvis leder till ett minskat intresse för "andliga " frågor i en vidare mening. Även i högt utvecklade länder skulle människor sträva efter att öka sin livskvalitet, inte minst när det gäller att finna mening i tillvaron: »The need for meaning becomes more salient at high levels of existential security so that, even in rich countries, although church attendance is declining, spiritual concerns more broadly are not disappearing" (Norris \& Inglehart 2004 s. 75). Som empiriskt belägg för denna hypotes kunde de visa att de som sade sig fundera över meningen med livet blev fler samtidigt som de som var engagerade i kyrkor och samfund blev färre. Med den diskussionen kommer man emellertid in på skillnaden mellan de båda religionsbegrepp som diskuterades i inledningen till denna artikel, och antagandet är exempel på hur ekonomisk och social utveckling kan leda till en religiös förändring som innebär att en viss religionsform (transcendensreligion) med tiden ersätts av en annan (immanensreligion) utan att för den skulle den totala omfattningen av religion skulle för- ändras. Problematiken berör också frågan om i vilken utsträckning intresse för livets mening med nödvändighet måste tolkas som ett "religiöst" uttryck (jfr. Hamberg 2008).

En viktigare aspekt i vårt sammanhang är emellertid att ekonomisk och social utveckling också kan påverka omfattningen av det religiösa engagemanget genom olika mekanismer, och att betydelsen av ökad existentiell säkerhet och trygghet långtifrån är den enda. Man har exempelvis också pekat på differentiering, urbanisering och industrialisering som avgörande faktorer (se t.ex. Luckmann 1967, Roof 1978, Berger 1980, Wilson 1982, Bruce 1999). Andra har framhållit betydelsen av rationalisering och ökad utbildning som avgörande faktorer bakom tillbakagången för den kyrkoorienterade religionen (se t.ex. Feldman \& Newcomb 1969, Hunsberger 1985, Johnson 1997). Tesen om att ekonomisk utveckling leder till religiös tillbakagång via ökad existentiell säkerhet är med andra ord enbart en av flera modeller för hur modernisering och ekonomisk utveckling har negativ betydelse för religionens del. En relativt ny aspekt av denna problematik handlar för övrigt om att det senmoderna samhället alltmer utvecklas till att bli ett så kallat risksamhälle där "the threats produced so far on the path of industrial society begin to predominate» (Beck 1994 s. 6, jfr. Beck 1992). De växande riskerna med kärnkraft, kärnvapen, klimatförändring, miljöförstöring, biogenetiska manipulationer, kemiska avfall, etc., har sagts öka människors känsla av risk och osäkerhet. Detta skulle sedan i sin tur i enlighet med tesen om att religionens betydelse ligger 
i att motverka osäkerhet leda till ett ökat religiöst engagemang (jfr. Giddens 1991 s. 207, Berger 1999). Angtagandet att länder med en långt gången modernisering med nödvändighet skulle kännetecknas av lägre nivåer för ett religiöst engagemang kan med andra ord problematiseras med hänvisning till att dessa länder i ökad utsträckning har kommit att bli risksamhällen och att religionen därmed möts av förnyat intresse som en motvikt mot de ökade riskerna.

\section{Tes 2: Modernisering och religiös avregle-} ring stärker kyrkoorienterad religion: Inom främst amerikansk religionssociologi har en ny syn på sekularisering vuxit fram under de senaste decennierna. Bakgrunden är att den nordamerikanska religiösa situationen har utvecklats på ett radikalt annorlunda sätt än den europeiska. För USA:s del har det varit naturligt att utveckla teoretiska modeller för varför den »religiösa ekonomin» (den religiösa sektorn) har förblivit vital, medan det för Europas vidkommande har varit mer naturligt att söka förklaringar till religiös stagnation och tillbakagång. En viktig utgångspunkt i det nya teoretiska perspektivet som har inspirerats av ekonomisk teoribildning är att fri konkurrens mellan kyrkor och samfund inom en avreglerad religiös ekonomi skulle leda till ökat religiöst deltagande (t.ex. Stark \& Finke 2000, Finke \& Stark 2003, Chaves \& Gorski 2001). Förklaringen skulle vara att utbudet på en avreglerad pluralistisk religiös marknad är bättre anpassat till människors religiösa efterfrågan samt att mer monopolistiska och reglerade religiösa ekonomier erbjuder ett mindre attraktivt religiöst utbud av sämre kvalitet. Nivåerna för det religiösa deltagandet tänks med andra ord inte spegla genuina skillnader i den grundläggande religiösa efterfrågan. Denna antas i stället vara mer eller mindre konstant, ett antagande som snarast utgör en utgångspunkt a priori inom den nya teoribildningen.

För svenskt vidkommande har olika studier kunnat visa att kommuner med ett mer varierat gudstjänstutbud tack vare detta visar högre nivåer för den kyrkoorienterade religionen. Studierna har också visat att församlingar inom ett och samma samfund (Svenska kyrkan) som har ändrat sitt gudstjänstutbud så att detta har blivit mer varierat och mångsidigt som en konsekvens av denna förändring har fått ökat gudstjänstdeltagande (Pettersson 2001, Pettersson \& Hamberg 1997, 1997b, Hamberg \& Pettersson 1994, 1997a, 2002). Utbudsteorin har med andra ord också visat sig fungera $\mathrm{i}$ ett land som under mycket lång tid har dominerats av ett enda samfund som närmast har varit ett religiöst monopol inom en starkt reglerad religiös ekonomi.

Sammanfattningsvis kan man således konstatera att en stor del av dagens sekulariseringsteoretiska diskussioner förs mellan två konkurrerade perspektiv. Det ena ser sekularisering och minskad kyrkoorienterad religion som en konsekvens av ekonomisk och social utveckling, till exempel av att allt färre upplever existentiell osäkerhet vilket i sin tur skulle resultera i minskad efterfrågan på kyrkoorienterad religion. Det andra perspektivet tar i stället fasta på strukturen och kvaliteten hos det religiösa utbudet och hävdar att en mindre reglerad och mer pluralistisk religiös ekonomi leder till ett kvalitativt bättre gudstjänstutbud

Thorleif Pettersson: Religion och samhällspraktik. En jämförande analys av... 
som i sin tur skulle leda till ett ökat religiöst deltagande.

Man kan hävda att diskussionen mellan dessa båda perspektiv har blivit alltför polariserad. Företrädare för utbudsteorin har exempelvis framhållit att det är dags att ta ett slutligt farväl av de äldre sekulariseringsteorierna genom att en gång för alla begrava dem på de felaktiga teoriernas kyrkogård under tonvis av empiriska belägg för deras felaktighet (Stark \& Finke 2000 s. 33, 79). Försvararna av de klassiska sekulariseringsteorierna har för sin del framhållit att utbudsteoretikernas kritik bör tystas en gång för alla genom att ett spjut kastas genom drakens hjärta (Bruce 1999 s. 2). Nästa avsnitt kommer att visa att det finns anledning till mer nyanserade synsätt och att sådana ensidiga antingen - eller argument skjuter högt över målet.

\section{En jämförande analys av två sekulariseringsteoretiska teser}

Som material för analyserna av de båda teoretiska perspektiven på religiös förändring kommer uppgifter om den kyrkoorienterade religionen från den senaste WVS-omgången år 2006 att användas. Anledningen är att dessa uppgifter kan kombineras med ny information om hur reglerade olika länders religiösa ekonomier är. En begränsning är emellertid att materialet enbart tillåter en analys av 26 länder. Begränsningen sammanhänger med att de länder som ingår i analysen bör tillhöra samma religio-kulturella tradition, nämligen den kristna. Därigenom minimeras inflytandet från teoretiskt ovidkom- mande och svårkontrollerbara faktorer. De 26 länderna är Andorra, Argentina, Österrike, Bulgarien, Brasilien, Chile, Cypern, Finland, Guatemala, Italien, Kanada, Moldavien, Mexiko, Norge, Peru, Polen, Rumänien, Slovenien, Spanien, Sverige, Sydafrika, Trinidad och Tobago, Tyskland, Ukraina, Uruguay och USA. Både när det gäller graden av ekonomisk utveckling och graden av religiös reglering finns betydande skillnader mellan dessa länder.

\section{Graden av religiös reglering}

Utbudsteoretiska undersökningar av sambandet mellan graden av religiös reglering och styrkan hos den kyrkoorienterade religionen har under lång tid försvårats av brist på jämförbara uppgifter om hur reglerade olika länders religiösa ekonomier är. Numer har dock denna brist avhjälpts genom tillkomsten av en ny databas: "Religion and state data set“ (se Fox 2008). Databasen innehåller uppgifter för 175 länder om fem grundläggande aspekter av religiös reglering. De fem aspekterna avser:

1. Vilken officiell roll religionen har i förhållande till staten

2. Huruvida staten motverkar eller stödjer någon av de förekommande religionerna

3. Vilka begränsningar som gäller för eventuella minoritetsreligioner

4. Graden av reglering av majoritetsreligionen, alternativt av samtliga förekommande religioner

5. I vilken utsträckning det finns lagstiftning som berör religionen 
För var och en av dessa aspekter innehåller databasen information om en rad delaspekter. Denna information har därefter sammanförts till ett övergripande mått på graden av religiös reglering (det så kallade GIR-måttet; "Government In Religion"). Måttet är beräknat så att det kan variera mellan 0 och 100. Ett lågt värde innebär en lägre grad av reglering. USA visar sig ha det lägsta värdet av samtliga undersökta länder och Saudiarabien det högsta. Även om man kan vara kritisk till olika delaspekter av GIR-måttet finns för närvarande knappast något bättre. GIR-måttet kan med hjälp av formeln (100 - GIR) lätt transformeras till ett mått på graden av religiös avreglering.

Enligt allmän moderniseringsteori bör den religiösa regleringen minska i takt med att samhället moderniseras. Uppgifterna i den aktuella databasen stöder emellertid inte detta antagande (Fox 2008 kap. 4). I så gott som vart och ett av de aktuella länderna finns någon form av reglering av den religiösa sektorn, oavsett hur moderniserade länderna är. Det finns heller inte något entydigt samband mellan graden av ekonomisk utveckling och graden av religiös avreglering och regleringen har snarare ökat än minskat under det senaste decenniet. Däremot finns ett klart samband mellan graden av demokratisering och graden av religiös avreglering. De länder som är mer demokratiserade tenderar att vara mindre reglerade (Fox 2008 kap. 4). Eftersom ekonomisk utveckling ofta leder till demokratisering (jfr. Inglehart \& Welzel 2005) kan man således hävda att ekonomisk utveckling leder till en avreglerad religiös sektor via att länderna demokratiseras men först i ett längre tidsperspektiv.

\section{Graden avekonomisk utveckling och religiös avreglering $i 26$ länder}

Sambandet mellan graden av utveckling och religiös avreglering i de 26 länderna framgår av Figur 2 nedan. Måtten på dessa båda aspekter har transformerats till så kallade z-poäng. Figur 2 visar i enlighet med vad som sades ovan inte något entydigt samband mellan de båda dimensionerna $(\mathrm{r}=0,05)$. Sydafrika (ZAF) har de mest gynnsamma förutsättningarna för en stark kyrkoorienterad religion (sämre utveckling, högre avreglering) medan Finland och Spanien har de minst gynnsamma (bättre utveckling, lägre avreglering). Sverige har ungefär samma principiella förutsättningar som Italien.

Den fråga som de båda sekulariseringsteoretiska teserna ger upphov till handlar således om vilka samband som finns mellan styrkan hos den kyrkoorienterade religionen på den ena sidan och graden av utveckling och religiös avreglering på den andra. En regressionsanalys med länderna som enheter och graden av kyrkoorienterad religion som beroende variabel och graden av utveckling (HDI-indexet) och religiös avreglering (det omvända GIR-måttet) som oberoende variabler ger ett första svar på frågan. Resultaten visar att graden av utveckling har säkerställd negativ betydelse för den kyrkoorienterade religionen medan graden av religiös avreglering har en säkerställd positiv betydelse. Betydelsen av dessa båda faktorer är dessutom säkerställd även då man kontrollerar för vilken religiös tradition (katolsk, protestantisk, ortodox) som dominerar i de aktuella län-

Thorleif Pettersson: Religion och samhällspraktik. En jämförande analys av... 
derna. Var och en av de båda teserna om den kyrkoorienterade religionens styrka har således fått empiriskt stöd. ${ }^{6}$ En mer detaljerad hierarkisk regressionsanalys som samtidigt beaktar betydelsen av faktorer på både makro- och mikronivå visar samma resultat. Betydelsen av de båda faktorerna på samhällsnivå visar sig således vara obe-

6 Om man anger den kyrkoorienterade religionen på en skala med medelvärdet 100 och standardavvikelsen 100 får den ostandardiserade regressionsekvationen följande form: Kyrkorienterad religion $=97,01-\left(3,99{ }^{*} \mathrm{HDI}\right)+\left(2,47^{*}\right.$ graden av religiös avreglering $)+\left(3,40^{*}\right.$ katolsk tradition $)+\left(2,41^{*}\right.$ protestantisk tradition $)+$ $\left(2,56^{*}\right.$ ortodox tradition). Enbart de två förstnämnda oberoende variablerna är signifikanta: $\mathrm{p}<, 01$ resp $\mathrm{p}<, 03$. Länder med blandad religiös tradition är referenskategori. $\mathrm{R} 2=, 62$. roende av inflytandet från sådana faktorer på individnivå som tidigare forskning har visat påverkar den kyrkoorienterade religionen.

De regressionsanalyser som redovisades ovan bortser från tidsförhållandena mellan på ena sidan en viss nivå för graden av utveckling och religiös avreglering och på andra sidan styrkan hos den kyrkoorienterade religionen. Teoretiskt finns emellertid skäl att räkna med en tidsfördröjning som innebär att en förändrad utvecklings- och avregleringsnivå först efter viss tid slår igenom i en förändrad styrka hos den kyrkoorienterade religionen. Förklaringen skulle vara att styrkan hos den kyrkoorienterade religionen på individnivå bestäms under individernas formbara barn- och ungdomsår och att den därefter tenderar att vara jäm-

\section{Figur 2.}

Human Development Index och graden av religiös avreglering $i 26$ länder med en dominerande kristen religiös tradition.

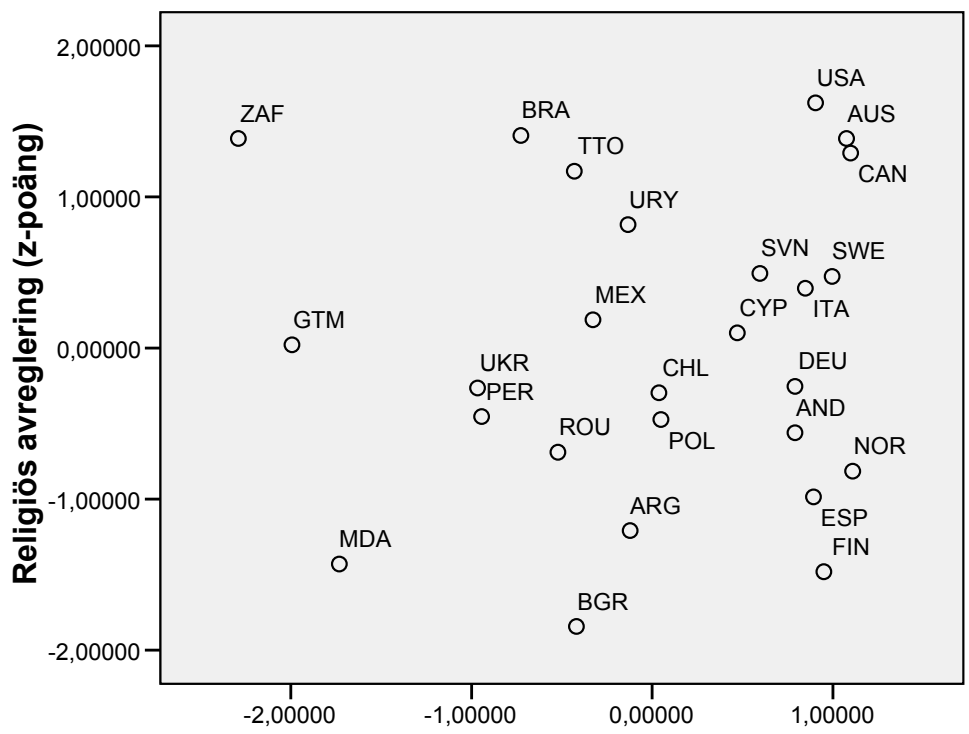

Human Development Index 2006 (z-poäng) 
förelsevis intakt. Successiva effekter av ekonomisk utveckling och religiös avreglering skulle med andra ord först bli märkbara hos de nytillkommande generationerna. Kommande studier får visa i vilken utsträckning en sådan hypotes har fog för sig.

Sammanfattningsvis ger således resultaten upphov till en hypotes om att två olika delaspekter av samhällets modernisering och utveckling har motsatta effekter på den kyrkoorienterade religionen. Ekonomisk utveckling leder till ökad existentiell säkerhet, ökad utbildning, ökad urbanisering, etc., och därigenom till att den kyrkoorienterade religionen försvagas. Samtidigt antas modernisering och ekonomisk utveckling leda till ökad demokratisering och därmed till minskad reglering av den religiösa sektorn. Den minskade regleringen skulle sedan på sikt leda till ökad kyrkoorienterad religion via ett kvalitativt bättre religiöst utbud. Det vore med andra ord alltför förenklat att anta att modernisering och ekonomisk utveckling enbart skulle ha negativ betydelse för den kyrkoorienterade religionen. De marginella och osystematiska förändringar i den kyrkoorienterade religionen som redovisades tidigare i artikeln bör ses mot denna bakgrund av två motverkande aspekter av modernisering och ekonomisk utveckling som tenderar att "låsa fast» den kyrkoorienterade religionen på en relativt oförändrad nivå.

\section{Har religionen praktisk betydelse för politik och social förändring?}

Hur stark den kyrkorienterade religionen är och hur den har förändrats över tid är viktiga aspekter av hur långt gången sekulariseringen är. En minst lika viktig sekulariseringsteoretisk fråga handlar om vilken betydelse den kyrkoorienterade religionen har för politik och samhälle. I anslutning till begreppen "mental sekularisering" och "kompartmentalisering" (jfr. tidigare i artikeln om detta) kan man för det första fråga om människor faktiskt vill att religionen skall ha någon sådan betydelse eller om de i stället föredrar att sådant som har med politik och samhällsfrågor att göra skall vara frikopplat från ett religiöst inflytande. För det andra kan man fråga om religionen har någon faktisk betydelse eller inte, bortsett från vilka önskemål som finns om detta. En sådan betydelse kan dessutom visa sig på åtminstone två olika sätt. För det första kan ett religiöst engagemang leda till att man kommer att hysa speciella uppfattningar i olika samhällsfrågor, exempelvis till en negativ syn på aborter eller en positiv syn på bistånd till utvecklingsländer. För det andra kan det religiösa engagemanget påverka stabiliteten hos individernas uppfattningar i olika samhällsfrågor, oavsett vilka åsikter de har. Även om de som är religiöst engagerade inte skulle ha en gemensam syn på exempelvis abort- eller biståndsfrågan kan deras skilda uppfattningar i dessa frågor bli mer stabila genom sin koppling till individernas religiösa trosföreställningar, som ofta är relativt oföränderliga över individernas livslopp. Betydelsen hos det religiösa engagemanget skulle med andra ord vara att det ger en religiös legitimering till individernas uppfattningar i olika samhällsfrågor (jfr. Hart 1996).

Thorleif Pettersson: Religion och samhällspraktik. En jämförande analys av... 


\section{Två aspekter av religionens betydelse för politik och social förändring}

Problemet om vad människor anser om religionens betydelse för politik och social förändring kan för det första gälla hur öppna de är för att religiösa talesmän deltar i den politiska opinionsbildningen, oavsett vad de anser om deras förslag. Denna aspekt kan sägas handla om en demokratisk öppenhet för att skilda ideologiska aktörer är aktiva i politikens värld, oavsett vilka ställningstaganden de representerar. För det andra handlar problemet om vad människor anser om religionens betydelse för politik och sociala frågor om i vilken utsträckning de anser att politiken skulle bli bättre eller sämre med en religiös påverkan. Man kan i demokratisk anda vara öppen för att religiösa talesmän försöker påverka politiken även om man anser att deras förslag skulle göra politiken sämre.

För att undersöka dessa båda aspekter av "mental sekularisering" kan man använda sig av svaren till ett mindre frågebatteri med fyra påståenden som användes i den senaste omgången av World Values Survey. Svarspersonerna fick ange i vilken utsträckning de höll med om eller tog avstånd från de aktuella påståendena. Vid samtliga påståenden användes en femgradig svarsskala som gick från "Håller starkt med" (värdet 1) till »Tar starkt avstånd ( (värdet 5). Två av påståendena hade följande lydelse: "Religiösa ledare ska inte påverka beslut i riksdag och regering" respektive "Religiösa ledare ska inte påverka hur folk röstar i de allmänna valen«. Den gemensamma nämnaren i dessa båda påståenden är att man är negativ till att religiösa talesmän deltar i den politiska opinionsbildningen. Två andra påståenden hade följande lydelse: „Det skulle vara bättre för (det egna landet) om fler människor med stark religiös tro hade statliga och kommunala uppdrag" respektive „Politiker som inte tror på Gud är olämpliga för statliga och kommunala uppdrag och tjänster". Genom

\section{Tabell 4.}

Resultat från en konfirmatorisk faktoranalys av 4 indikatorer för två aspekter av förhållandet mellan religion och politik. Resultat från 2006 års WVS-undersökning i 26 länder.

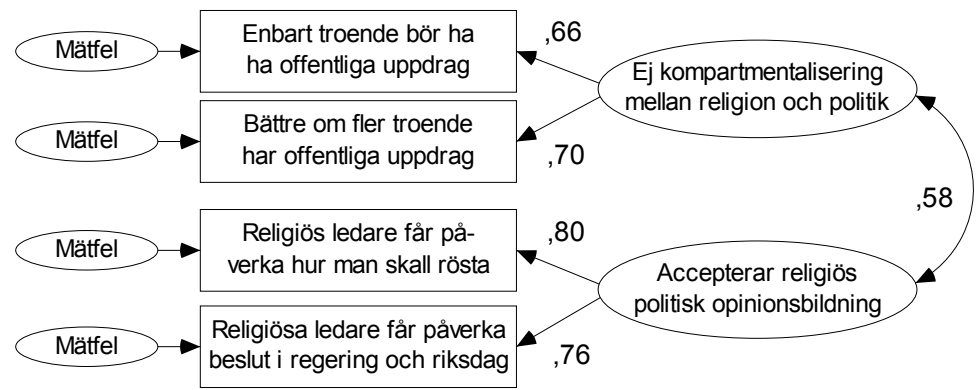

Chi-square/df $=7,76$, AGFI $=0,98$, RMSEA $=0,06, \mathrm{n}=29803$. Resultat för prövning av samma trefaktorstruktur med samma faktorladdningar och covarianser mellan faktorer i vart och ett av 26 länder med ca. 1000 svarspersoner per land: $\mathrm{Chi} / \mathrm{square} / \mathrm{df}=7,95, \mathrm{AGFI}=0,95, \mathrm{RMSEA}=0,02$. 
att hålla med om dessa båda påståenden ger man uttryck för uppfattningen att religion har positiv betydelse för politik och samhällsfrågor och att det följaktligen vore bra med en religiös påverkan på politik och samhällsfrågor.

Tabell 4 visar resultatet av en konfirmatorisk faktoranalys av svaren till det aktuella frågebatteriet. Vid analysen har svaren till de två sistnämnda frågorna kodats om så att ett högre värde visar att man instämmer i dem (det vill säga att man inte önskar en åtskillnad mellan religion och politik). Resultaten visar att de aktuella indikatorerna kan användas för att fånga de båda aspekterna av förhållandet mellan religion och politik samt att de ger jämförbara resultat för de aktuella länderna. En kontrollanalys med de indikatorer som har använts för att mäta den kyrkoorienterade religionen visar dessutom att faktorstrukturen hos de fyra påståendena är oberoende av indikatorerna för den kyrkoorienterade religionen. Man kan därför använda de aktuella indikatorerna för att undersöka samband som finns mellan den kyrkoorienterade religionen å ena sidan och de två aspekterna av religionens betydelse å den andra.

\section{Uppfattningarom förhållandet mellan religion och politik i 26 länder}

Figur 3 visar hur de 26 länderna skiljer sig åt vid de båda synsätten på förhållandet mellan religion och politik. De mått som Figur 3 bygger på har beräknats utifrån resultaten av den faktoranalys som redovi- sades i Tabell 4 och de har konstruerats för att ge ett totalt medelvärde om 100 och en standardavvikelse om 10 för samtliga svarspersoner som ingår i analysen. Figuren visar ett starkt samband mellan en önskan om att religionen skall påverka politiken (önskar ej en åtskillnad mellan dessa båda storheter) och en öppenhet för att religiösa talesmän deltar i den politiska opinionsbildningen $(\mathrm{r}=, 57 ; \mathrm{p}<, 01)$.

De båda aspekterna av förhållandet mellan religion och politik har positivt samband på den aggregerade nivån med hur stark den kyrkoorienterade religionen är: Ju starkare kyrkoorienterad religion, desto mer föredrar man att religionen skall påverka politiken och desto mer positiv är man till att religiösa ledare deltar i den politiska opinionsbildningen. Dessutom visar sig ett negativt samband mellan hur demokratiserade länderna är och hur positiva befolkningarna är till att religiösa talesmän deltar i den politiska opinionsbildningen $(r=-, 57$; $p<, 02)$. Det ofta upprepade talesättet att en demokrati skulle förutsätta att man är beredd watt ge sitt liv« för någons rätt att delta i den politiska opinionsbildningen även om man inte delar vederbörandes synsätt får med andra ord inte något stöd av det aktuella materialet.

Sverige visar jämförelsevis låga värden $\mathrm{i}$ både öppenheten för att religiösa talesmän skall delta i den politiska opinionsbildningen och i önskemålet att religionen skall påverka politiken. Man bör dock notera att Norge är ännu mer särpräglat än Sverige i dessa hänseenden. Länder som däremot ligger högt i den kyrkoorienterade religionen (exempelvis USA, Mexiko, Peru, Brasilien och Sydafrika) visar däremot höga 
värden i de båda aspekterna av förhållandet mellan religion och politik.

\section{Religionens betydelse för politik och social förändring; en analys på tre nivåer}

I jämförelse med andra nationaliteter är således svenskarna mindre engagerade i den kyrkoorienterade religionen, mer negativa till att religiösa talesmän deltar i den politiska opinionsbildningen och mer positiva till att religion och politik skall vara åtskilda. Det ligger därför nära till hands att anta att den kyrkoorienterade religionen skulle sakna betydelse för dagens svenska samhällspraktik. Den avslutande delen av artikeln kommer att presentera tre argument för varför en sådan hypotes är förhastad.

\section{Kyrkoorienterad religion påverkaruppfattningarom bio-etiska moralfraigor}

WVS-formuläret innehåller en rad frågor om hur svarspersonerna ser på olika moralfrågor. Man kan därför analysera vad deras kyrkoorienterade religiösa engagemang betyder för deras moraliska synsätt. Enligt tidigare studier tenderar de som har det starkaste religiösa engagemanget att vara mest restriktiva när det gäller att acceptera olika typer av moraliska "försyndelser». Av utrymmesskäl kommer artikeln emellertid

Figur 3.

Uppfattningar om religionens betydelse för politik i 26 länder. Resultat från 2006 års WVSomgång i 26 länder.

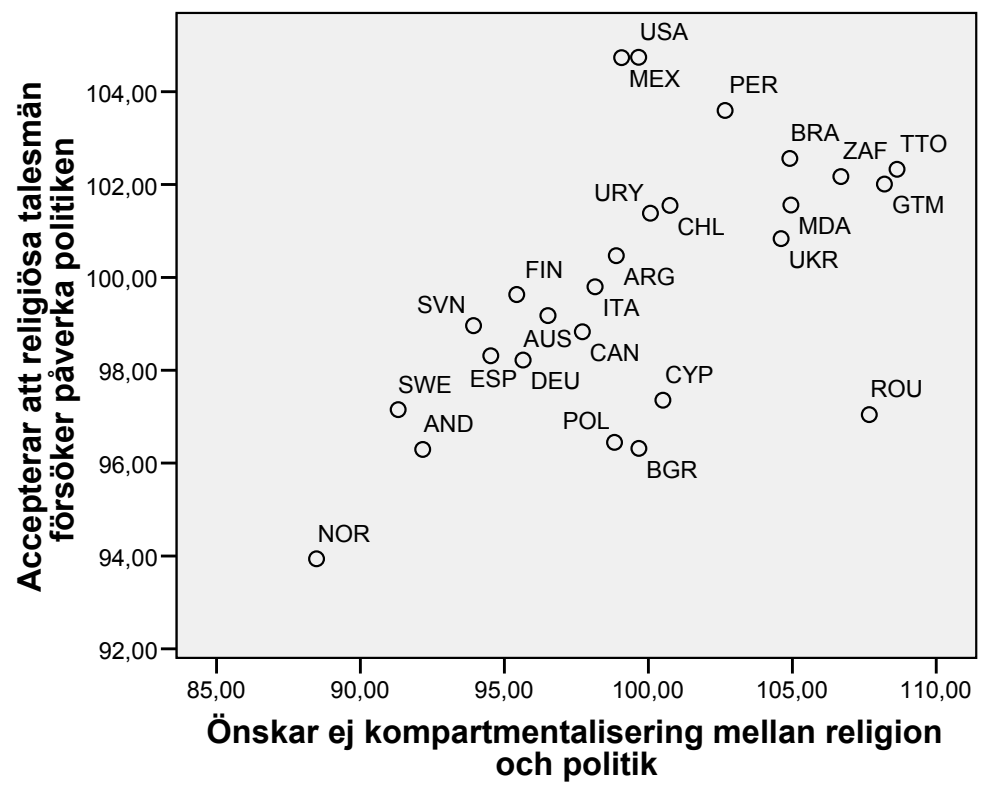

Socialvetenskaplig tidskrift nr 3-4 • 2009 
enbart att beakta hur man ser på abort och homosexualitet. Frågeformuläret till WVSundersökningen innehöll två frågor om i vilken utsträckning man ansåg att abort och homosexualitet kunde rättfärdigas. Svaren gavs på en 10-gradig svarsskala som gick från "Kan aldrig rättfärdigas» (värdet 1) till „Kan alltid rättfärdigas» (värdet 10). Resultaten från en serie stegvisa regressionsanalyser, en för varje land, visar hur stor andel av den totala variationen i de moraliska bedömningarna som den kyrkoorienterade religionen förmår förklara sedan man först har tagit hänsyn till den individualistiska grundhållningen och sociala bakgrundsvariabler som kön, ålder och utbildning. Resultaten sammanfattas grafiskt i Figur 4.
Den kyrkoorienterade religionen är med ett enda undantag kopplad till en mer restriktiv syn på abort och homosexualitet. Den andel av den totala variationen i de båda moraliska bedömningarna som förklaras av den kyrkoorienterade religionen är dessutom med något undantag statistiskt säkerställd. Mot denna bakgrund kan man förenklat säga att Figur 4 visar tre grupper av länder. Den första gruppen utgörs av USA där den kyrkoorienterade religionen förmår förklara ungefär 20 procent av de moraliska bedömningarna av abort och homosexualitet. Därefter kommer en grupp av länder (Italien, Polen, Spanien, Andorra, Australien och Kanada) där den kyrkoorienterade religionen förklarar knappa 20 procent av synen på abort och

\section{Figur 4.}

Förklaringskraft hos den kyrkorienterade religionen vid instälning till abort och homosexualitet. Resultat från 2006 års WVS-omgång i 24 länder.

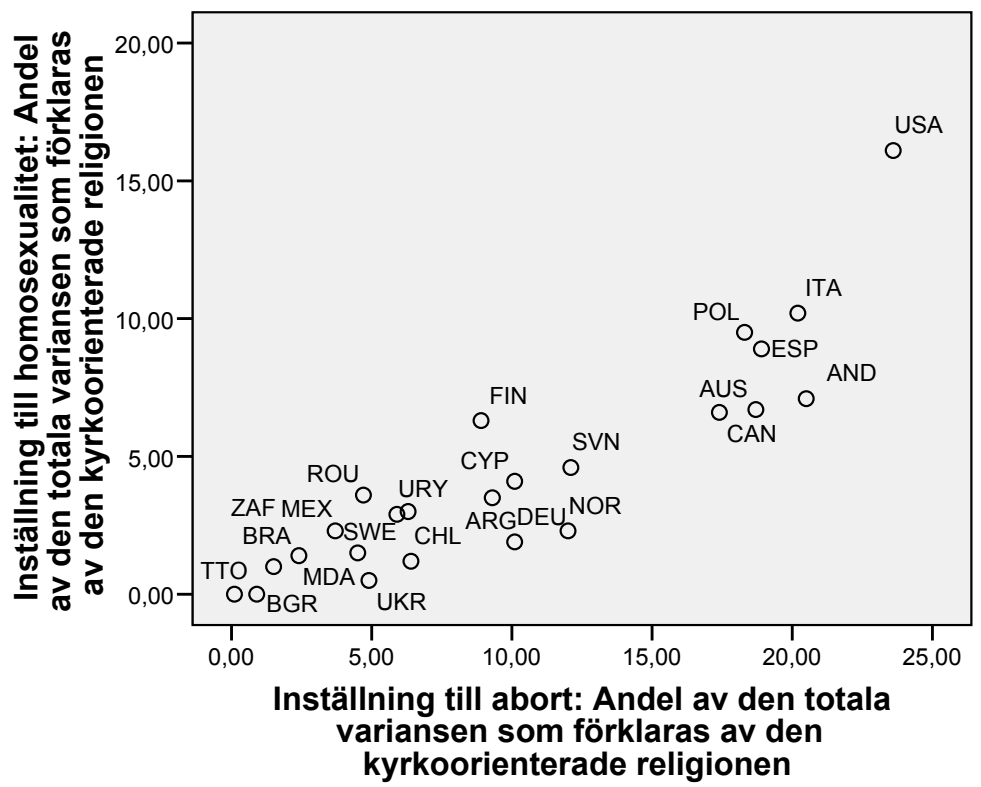

Thorleif Pettersson: Religion och samhällspraktik. En jämförande analys av... 
knappa 10 procent av synen på homosexualitet. Slutligen kommer en tredje grupp där den kyrkoorienterade religionen som mest förmår förklara dryga 10 procent av synen på abort och 5 procent av synen på homosexualitet. Sverige befinner sig i denna grupp tillsammans med länder som Argentina, Rumänien, Mexiko och Brasilien. Ett tidigare resultat visade emellertid att den kyrkoorienterade religionen var betydligt starkare i dessa länder än i Sverige och att fler var positiva till att religionen skall påverka politik och samhälle.

Även om den kyrkoorienterade religionen är jämförelsevis svag i Sverige och det är jämförelsevis få svenskar som önskar att den skall påverka politik och samhälle förklarar den således i statistisk mening lika mycket - eller lika litet - av svenskarnas moraliska uppfattningar som den gör i länder där den är betydligt starkare och det är fler som är positiva till dess samhälleliga betydelse. Två aspekter av sekularisering (styrkan hos den kyrkoorienterade religionen respektive vilken betydelse den har för uppfattningar i olika samhällsfrågor) visar sig med andra ord inte gå hand $i$ hand. Om man enbart ser till dess betydelse för människors bio-etiska moral förefaller således den kyrkoorienterade religionen vara lika relevant i Sverige som den är i länder där den är betydligt starkare.

\section{Betydande utåtriktat socialt arbete frain trossamfunden}

En annan aspekt av vad religionen betyder för samhällspraktiken handlar om trossamfundens utåtriktade sociala arbete. Svenska kyrkor och samfund anslår betydande resurser till sådana ändamål. Cirka sex procent av den vuxna svenska befolkningen utför således någon form av frivilligt arbete inom ramen för någon religiös organisation (Olsson et al. 2009). En inte obetydlig del av detta arbete är inriktad på olika former av sociala insatser (Jeppson Grassman \& Svedberg 1999, Svedberg \& Olsson 2009). Svenska kyrkans sociala arbete har en omfattning som motsvarar ungefär 4000 heltidstjänster. Av dessa innehas ungefär 1500 av diakoner eller diakoniassistenter (Engel 2006 s. 11) och Svenska kyrkan anslår ungefär 400 miljoner kronor om året till sitt diakonala arbete. Till detta kommer de cirka 250 miljoner kronor som Stadsmissionerna i Stockholm, Göteborg, Malmö och Linköping anslår (Nyckeln till svenska kyrkan). På motsvarande sätt anslår de olika frikyrkorna betydande belopp till sitt utåtriktade arbete.

Svenska kyrkan anslår således betydande resurser till sitt sociala arbete. Även om detta kan ta många olika former (Engel 2006) anser kyrkans medlemmar att denna del av kyrkans verksamhet är mycket viktig (se t.ex. Centrum för samtidsanalys 2009, Sundback 2000, Pettersson et al. 1994, Tegborg 1978). Det gör inte minst de stora grupper av kyrkans medlemmar som inte delar kyrkans tro. Eftersom dessa grupper har svårt att legitimera sitt medlemskap i kyrkan med sin (bristande) religiösa tro motiverar de ofta medlemskapet med hänvisning till kyrkans sociala insatser. Och eftersom det av ekonomiska skäl är viktigt för kyrkan att behålla dessa stora grupper som medlemmar kommer deras förväntningar på ett utåtriktat socialt arbete att 
påverka kyrkans verksamhet $\mathrm{i}$ en sådan riktning.

\section{Kyrksamhet, socialt kapital och kommunal samhällspraktik}

Dagens samhällsvetenskapliga forskning visar stort intresse för horisontell social tillit och så kallat socialt kapital. Studier av dessa storheter ökade med mer än 15 gånger under den senaste 20-årsperioden (Rothstein \& Uslaner 2005 s. 42). Det ökade intresset har bland annat sagts bero på att vi nu skulle vara på väg mot en ny samhällsform där de tidigare grunderna för samverkan och integration håller på att luckras upp till förmån för nya mekanismer för samhällsordningen. En sådan ny mekanism sägs bygga på horisontell tillit mellan medborgarna (Aronsson \& Karlsson 2001). Det är därför inte svårt att förstå det stora intresset för tillit och socialt kapital som alltmer börjar ses som en grundläggande resurs för social, ekonomisk och politisk utveckling.

En intressant problematik handlar om vad religionen betyder i dessa hänseenden. I sin banbrytande italienska studie gav Robert Putnam uttryck för en negativ syn på religionens betydelse (Putnam 1996). I sina analyser av det försvagade civilsamhället i USA konstaterade han emellertid tio år senare att kyrkor och samfund sannolikt är den allra viktigaste reservoaren för socialt kapital (Putnam 2001). Frågan om vilka samband som finns mellan social tillit och religion har emellertid många bottnar och det är svårt att ge något entydigt svar. Det finns betydande skillnader, både mellan de stora världsreligionerna och mellan skilda traditioner inom dessa. Det finns dessutom olika sätt att förhålla sig till sin tro, till exempel att omfatta ett religiöst engagemang som ett mål i sig (så kallad intrinsikal religiositet) eller som medel till något annat (så kallad extrinsikal religiositet). Ett visst mönster kan visa sig då man jämför individer med olika förhållningssätt till sin tro och ett annat då man jämför medlemmar i samfund med olika teologiska profiler (Welch et al. 2004, Halman \& Pettersson 1999). Även om det knappast finns några heltäckande systematiska studier av denna problematik har det synsätt som Putnam gav uttryck för i sin italienska studie knappast vunnit allmän uppslutning. Det stora europeiska projektet "Beliefs in Government" sammanfattade exempelvis religionens betydelse genom att konstatera att den spelar en betydande roll för den sociala integrationen och att fortsatt tillbakagång för kyrkor och samfund skulle kunna leda till att medborgarandan försvagas (Gabriel 1995).

En undersökning av svenska förhållanden har visat att högre kyrksamhet bidrar till stabila sociala miljöer med färre våldsrelaterade brott, färre brott relaterade till alkoholmissbruk, färre skilsmässor och stabilare familjebildningar (Pettersson 1991). Eftersom stabila sociala miljöer är gynnsamma både för framväxt och vidmakthållande av social tillit, tyder resultatet på att förhållandet mellan religion och socialt kapital ligger mer i linje med den positiva uppfattning som Putnam gav uttryck för i sina senare arbeten. I samma riktning pekar en nyligen publicerad svensk studie av hur

Thorleif Pettersson: Religion och samhällspraktik. En jämförande analys av... 
nivåerna för den kommunala medborgarandan skilde sig åt mellan ett antal svenska kommuner (Pettersson \& Lundåsen 2009). Analysen visade att tilliten mellan kommuninvånarna var starkare i de kommuner som hade den högsta kyrksamheten. Förhållandet var oberoende av både sociala bakgrundsvariabler på individnivå och strukturella förhållanden på kommunnivå. Man kan således sammanfattningsvis konstatera att kyrkoorienterad religion via sin positiva betydelse för tillit och socialt kapital kan vara en inte oväsentlig faktor för politisk och social utveckling.

De svenskar som visar den starkaste uppslutningen runt den kyrkoorienterade religionen har ofta en speciell syn på olika samhällsfrågor. Utan att gå in på detaljer kan man konstatera att de tenderar att sympatisera med Kristdemokraterna. De brukar också ha en mer strikt ekonomisk moral och en mer negativ inställning till abort, suicid och eutanasi. På samma sätt brukar de ha en mer traditionell familjesyn, inklusive en mer negativ syn på skilsmässor. De brukar också vara mer negativa till jämställdhet och etnisk mångfald. Dessa synsätt är särskilt utmärkande för dem som har en positiv syn på att religion skall påverka politik och samhällsfrågor (jfr. tidigare i artikeln om detta).

För att undersöka om denna annorlunda samhällssyn har reell betydelse för samhällspraktiken i de svenska kommunerna kan man analysera huruvida kommuner där kyrksamheten är olika stark också skiljer sig åt i sin kommunala praktik. Om en starkare kyrksamhet visar sig vara kopplad till en annorlunda kommunal samhällspraktik i de hänseenden där de som är mest positiva till den kyrkoorienterade religionen har en annorlunda samhällssyn skulle detta tyda på att kyrksamheten har faktisk betydelse för hur den kommunala samhällspraktiken är utformad.

Utan att gå in på detaljer kan man konstatera att sådana analyser visar att en starkare kyrksamhet är relaterad till högre röstetal för Kristdemokraterna, färre anmälda brott och färre betalningsanmärkningar per capita, till färre kvinnliga kommunpolitiker och till färre förtroendevalda som har invandrarbakgrund. Sambanden är oberoende av andra aspekter av kommunernas sociala struktur, till exempel befolkningsstorlek, befolkningsförändringar, tätortsgrad, andel bostäder i allmännyttiga bostadsföretag, andel äldre, andel med invandrarbakgrund, andel födda utom Norden, medelinkomst, andel lågutbildade, andel jordbruksföretag per capita, andel förvärvsarbetande, andel arbetslösa samt andel konkurser per capita. Dessa resultat tyder onekligen på att den kyrkoorienterade religionen har reell betydelse för den kommunala samhällspraktiken, även om den inte är den enda faktorn i detta hänseende.

Den kyrkoorienterade religionen förefaller med andra ord påverka utformningen av den kommunala samhällspraktiken. Även om Sverige i ett internationellt perspektiv är mycket sekulariserat och även om andelen kyrksamma svenskar knappast uppgår till mer än en liten minoritet utgör de fortfarande en grupp som förefaller sätta sin speciella prägel på hur det sociala livet är utformat i de kommuner där de bor. På motsvarande sätt kan man konstatera att kyrkor och samfund i Sverige satsar bety- 
dande resurser på olika former av sociala insatser. Man kan också konstatera att den kyrkoorienterade religionen har ungefär lika stor betydelse för svenskarnas uppfattningar i olika moralfrågor som den har $\mathrm{i}$ länder där religionen har en betydligt star- kare ställning. Även om den kyrkoorienterade religionen är jämförelsevis svag i Sverige vore det med andra ord förhastat att bortse från den då man söker förstå den svenska samhällspraktiken.

\section{Litteratur}

Aronsson, G. \& Karlsson, J. (2001) »Tillit och tilllitsproblem". I G. Aronsson \& J. Karlsson (red.) Tillitens ansikten. Lund: Studentlitteratur.

Arts W., Hagenaars J. \& Halman L. (2003) The Cultural Diversity of European Unity. Leiden: Brill.

Beck, U. (1992) Risk Society. Towards a New Modernity. London: Sage Publications.

Beck, U. (1994) »The Reinvention of Politics: Towards a Theory of Reflexive Modernization". In U. Beck, A. Giddens \& S. Lash (eds.) Reflexive Modernization. Stanford: Stanford University Press.

Berger, P. (1980) The heretical imperative: Contemporary possibilities of religious affiliation. London: Collins.

Berger, P. (1999) "The desecularization of the world; A Global overview». In P. Berger (ed.) The desecularization of the world. Resurgent religion and world politics. Grand Rapids: Wm. B. Eerdmans Publishing Company.

Berger P., Berger B. \& Kellner H. (1974) The homeless mind. Modernization and consciousness. Hammondsworth: Penguin Books.

Blanck. D. \& Pettersson, T. (2006) "Strong Governance and Civic Participation: Some Notes on the Cultural Dimension of the Swedish Model«. In L. Harrison (ed.) Developing Cultures. Case Studies. London: Routledge.
Bruce, S. (1999) Choice and Religion: A Critique of Rational Choice Theory. Oxford: Oxford University Press.

Bäckström, A. (2008) „Religionens återkomst?». I L. Kanckos \& R. Kauranen (red.) Social samhörighet och religion. Festskrift till Susan Sundback. Åbo: Åbo Akademi University Press.

Casanova, J. (1994) Public Religions in the Modern World. Chicago: The University of Chicago Press.

Centrum för samtidsanalys (2009) Tro och andlig het i Sverige. Saltsjö-Duvnäs: Centrum för samtidsanalys.

Chaves, M. \& Gorski, Ph. (2001) „Religious Pluralism and Religious Participation". Annual Review of Sociology 27, pp. 261-281.

Dobbelaere, K. (2002) Secularization. An Analysis of Three Levels. Oxford: P.I.E.-Peter Lang.

Engel, C. (2006) Svenska kyrkans sociala arbeteför vem och varför. En religionssociologisk studie av ett diakonalt dilemma. Stockholm: Ersta Sköndal högskola.

Feldman, K. \& Newcomb, T.(1969) The impact of col lege on students. Vol 1: An analysis of four decades of research. San Fransisco: Jossey- Bass Inc.

Finke, R. \& Stark, R. (2003) »The Dynamics of Religious Economies". In M. Dillon (ed.) Handbook of the Sociology of Religion. Cambridge: Cambridge University Press.

Thorleif Pettersson: Religion och samhällspraktik. En jämförande analys av... 
Fiske, A. P. (1991) Structures of social life. New York $\mathrm{m} \mathrm{fl}$ : The Free Press.

Fox, J. (2008) A World Survey of Religion and the State. Cambridge: Cambridge University Press. Gabriel, O. (1995) „Political efficacy and trust». In J. van Deth \& E. Scarbrough (eds.) The impact of values. Oxford: Oxford University Press.

Giddens, A. (1991) Modernity and Selfidentity. Stanford: Stanford University Press.

Glock, Ch. \& Stark, R. (1965) Religion and society in tension. Chicago: Rand McNelly.

Gorski, R. (2000) "Historizicing the Secularization Debate: Church, State, and Society in Late Medieval and Early Modern Europe". American Sociological Review65, February, pp. 138-167.

Halman, L. \& Pettersson, T. (1999) „Religion and social capital revisited". In L. Halman \& O. Riis (eds.) Religion in secularizing society. The European's religion at the end of the $20^{\text {th }}$ century. Tilburg: Tilburg University Press.

Hamberg, E. (2008) "Unchurched Spirituality». In P. B. Clarke (ed.) The Oxford Handbook of the Sociology of Religion. Oxford: Oxford University Press.

Hamberg, E. \& Pettersson, T. (1994) „The religious market: Denominational competition and religious participation in contemporary Sweden". Journal for the scientific study of religion, 33, pp. 205-216.

Hamberg, E. \& Pettersson, T. (1997) "Short-Term Changes in Religious Supply and Church Attendance in Contemporary Sweden". Research for the social scientific study of religion, pp. 35-51.

Hamberg, E. \& Pettersson, T. (2002) "Religious markets: Supply, demand and rational choices". In T. Jelen (ed.) Sacred markets, sacred canopies: Essays on religious markets and religious pluralism. New York: Roman \& Littlefield.

Hart, S. (1996) What does the Lord require? How American Christians think about economic justice. New Brunswick: Rutger University Press.

Hunsberger, B. (1985) "Parent-university student agreement on religious and non-religious issues». Journal for the scientific study of religion, 24, 3, pp. 47-55.

Inglehart, R. \& Welzel, C. (2005) Modernization,
Cultural Change and Democracy: The Human Development Sequence. New York: Cambridge University Press.

Jeppson Grassman, E. \& Svedberg, L. (1999) „Medborgarskapets gestaltningar - insatser i och utanför föreningslivet». I E. Amnå (red.) Civilsamhället. Demoratiutredningens forskarvolym nr 8. SOU 1999: 84. Stockholm: Fritzes.

Johnson, C. (1997) „Formal education vs. religious belief". Journal for the scientific study of religion, 36, pp. 231-246.

Kaufmann D., Kraay A. \& Mastruzzi M. (2006) Governance matters. Aggregate and individual indicators for 1996 - 2005. Washington: The World Bank.

Luckmann, T. (1967) The invisible religion. The problem of religion in modern society. New York: McMillan.

Luckmann, T. (1990) "Shrinking transcendence, Expanding religion?». Sociological Analysis, 50, 2.

Lundåsen, S. \& Pettersson, T. (2009) "Att mäta tillit - teori- och metodproblem". I L. Trädgårdh (red.) Tillit i det moderna Sverige: den dumme svensken och andra mysterie. Stockholm: SNS Förlag.

Norris, P. \& Ingelhart, R. (2004) Sacreed and Secular: Religion and Politics Worlwide. Cambridge: Cambridge University press.

Olsson L., Jeppsson Grassman E. \& Svedberg L. (2009) Medborgarnas insatser och engagemang i civilsamhället: några grundläggande uppgifter från en ny befolkningsstudie. Sköndalsinstitutets arbetsrapportserie nr 39. Stockholm: Ersta Sköndal högskola.

Pettersson, T. (1991) „Religion and criminality. Structural relationships between church involvement and crime rates in contemporary Sweden". Journal for the scientific study of religion, 30, pp. 279-291.

Pettersson T., Geyer K. \& Wikström O. (1994) "Gudstjänstbesökarna». Tro \& tanke 1994: 9.

Pettersson, T. \& Hamberg, E. (1997) "Söndrade vi stå, enade vi falla. En studie av mångfald och medlemstal bland svenska frikyrkor 19741995«. Tro och Tanke 1997, 3. 
Pettersson, T. \& Hamberg, E. (1997b) „Denominational Pluralism and Church Membership in Contemporary Sweden". Journal of empirical theology 10:2, pp. 61-78.

Pettersson, T. (2000) „Moral och mänskliga relationer». I G. Gustafsson \& T. Pettersson (red.), Folkkyrkor och religiös pluralism - den nordiska religiösa modellen. Stockholm: Verbum.

Pettersson, T. (2001) „Många eller få? Drygt en halv miljon kyrkobesök under ett veckoslut«. I M. Skog (red.) Det religiösa Sverige. Gudstjänst- och andaktsliv under ett veckoslut vid millennieskift. Örebro: Libris.

Pettersson, T. \& Esmer, Y. (2005) Vilka är annorlunda? Om invandrares möte med svensk kultur. Integrationsverkets rapportserie 2005:3. Norrköping: Integrationsverket.

Pettersson, T. \& Nurmela, S. (2007) Om olika sätt att möta en stor elefant. En jämförande studie av finländsk och svensk kultur, www.kulturfonden.net (http://www.kulturfonden.net/ upload/rapport.2.11.07.pdf).

Pettersson, T. (2008) Unga sjunga med de gamla! En jämförande analys av grundläggande värderingar och uppfattningar om demokrati och politik bland blivande vuxna. Rapport R-08-53. Stockholm: SKB.

Pettersson, T. \& Lundåsen, S. (2009) »Tillit, medborgaranda och kommunpolitik". I L. Trädgårdh (red.) Tillit $i$ det moderna Sverige: den dumme svensken och andra mysterier. Stockholm: SNS Förlag.

Putnam, R. (1996) Den fungerande demokratin. Medborgarandans rötter i Italien. Stockholm: SNS Förlag.

Putnam, R. (2001) Den ensamme bowlaren. Den amerikanska medborgarandans upplösning och förnyelse. Stockholm: SNS Förlag.

Repstad, P. (1996) „Introduction: A paradigm shift in the sociology of religion«. In P. Repstad (ed.) Religion and modernity. Modes of co-existence. Oslo $\mathrm{m}$ fl: Scandinavian university Press.

Roof, W. C. (1978) Community \& commitment. Religious plausibility in a liberal protestant church. New York: Elsevier.

Rothstein, B. (2001) Sociala fällor och tillitens pro- blem. Stockholm: SNS Förlag.

Rothstein, B. \& Uslaner, E. (2005) "All for all. Equality, corruption and social trustw. World Politics, 58, pp. 41-72.

Sachsenmaier, D. \& Riedel, J. with Eisenstadt, S. (2002) Multiple modernities. European, Chinese \& other interpretaions. Leiden: Brill.

Stark, R. \& McCann, J. (1993) „Market forces and Catholic commitment: Exploring the new paradigm". Journal for the scientific study of religion, 32, pp. 111-124.

Stark, R. \& Finke, R. (2000) Acts of Faith: Explaining the Human Side of Religion. Berkeley: University of California Press.

Sundback, S. (2000) »Medlemskapet i de lutherska folkkyrkorna i Norden«. I G. Gustafsson \& T. Pettersson (red.) Folkkyrkor och religiös pluralism - den nordiska religiösa modellen. Stockholm: Verbum.

Svedberg, L. \& Olsson, L. E. (2009) „Civil Society and Welfare Provision in Sweden - Voice and Social Service». In A. Zimmer \& A. Evers (eds.) Third Society Orgainizations Facing Turbulent Environments: Sports, Culture and Social Services in Germany, Italy, U.K, Poland and Sweden. Baden-Baden: Nomos Verlag (in press).

Tegborg, L. (1978) Församlingen - vision och verklighet. Skara: Prästmöteavhandling för Skara stift.

Triandis, H. (1994) »Theoretical and methodological approaches to the study of collectivism and individualism». In U. Kim, H. C. Triandis, C. Kagiticibasi, S. Choi \& G. Yoon (eds.), Individualism and collectivism. Theory, methods, and applications. London $\mathrm{m} \mathrm{fl}$ : Sage.

Trägårdh, L. (2009) „Den dumme svensken och allemansrättens magi«. I L. Trägårdh (red.) Tillit $i$ det moderna Sverige. Den dumme svensken och andra mysterier. Stockholm: SNS förlag.

Welch M., Sikkink D., Sartain E. \& Bondet C. (2004) "Trust in God and Trust in Man: The Ambivalent Role of Religion in Shaping Dimensions of Social Trust». Journal for the Scientific Study of Religion, 43, 3, pp. 317-343.

Welzel, C. (2009) „How selfish are the self-expres-

Thorleif Pettersson: Religion och samhällspraktik. En jämförande analys av... 
sion values?». Antagen för publicering i Journal for cross-cultural psychology.

Wilson, B. (1982) Religion in sociological perspective. Oxford: Oxford University Press.

Woodhead, L. \& Heelas, P. (2000) Religion in modern times. Oxford: Blackwell publishers.
Österberg, E. (1993) „Vardagens sköra samförstånd. Bondepolitik i den svenska modellen från Vasatid till Frihetstid«. I G. Broberg, U. Wikander \& K. Åmark (red.) Tänka, tycka, tro. Stockholm: Ordfront.

\section{Internetkällor}

http://www.europeanvaluesstudy.eu/

http://www.worldvaluessurvey.org/

\section{Summary}

\section{Religion and social practice A comparative analysis of secularized Sweden}

The paper introduces a discussion of two models of religion: transcendent religions of difference and immanent spiritualities of life. Based on World Value Survey data from more than 50 countries, the paper then shows that two dimensions of Swedish popular culture are quite specific in an international perspective. The two dimensions are church-oriented religion and individualism. These two dimensions are related to the two kinds of religion. The Swedes are marked by low levels of church-oriented religious involvement and high levels of immanent individualism. The paper then presents a simultaneous cross-sectional analysis of two models of secularization: a newer supply side model which assumes a positive impact of religious deregulation, and a conventional model which assumes a negative impact of modernization and eco- nomic development. The two models are compared for a set of 26 countries with a predominantly Christian religious tradition. The supply side model is tested by the newly developed GIR (Government in Religion) measure and the conventional secularization model by the Human Development Index. The results demonstrate that each of the two contrasting models of secularization gains empirical support. This finding can then explain why there have been only minor changes in church-oriented religion during the last few decades. A concluding part of the paper demonstrates that even if the Swedish level of church-oriented religion is comparatively low by international standards, local religion in the Swedish municipalities still has a noticeable impact on local social life. 